
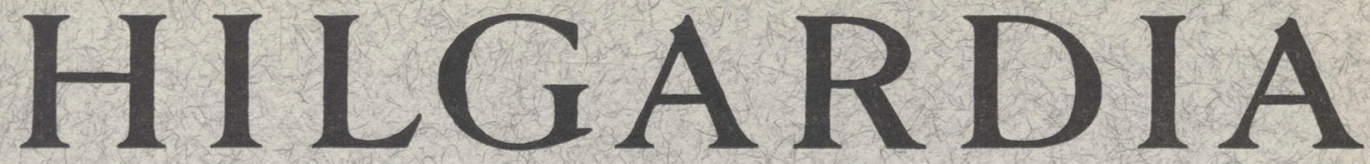

A Journal of Agricultural Science Published by the California Agricultural Experiment Station

GAINS AND LOSSES OF MINERAL ELEMENTS IN AN IRRIGATED SOIL DURING A 20-YEAR LYSIMETER INVESTIGATION

\author{
P. F. PRATT \\ and \\ H. D. CHAPMAN
}

UNIVERSITY OF CALIFORNIA - BERKELEY, CALIFORNIA 
In addition to data on nitrogen gains and losses, a summary of all data on gains and losses of seven other mineral elements in a soil irrigated, fertilized, and cropped for 20 years in large lysimeters is presented. Granitic-derived residual soil (Holland loam) was winter-treated with applications of cereal straw and with the growth of various covercrops, each in combination with nitrogen from $\mathrm{Ca}\left(\mathrm{NO}_{3}\right)_{2}$. Summer crops were barley and Sudangrass. Winter crops were returned to the soil, but summer crops were not. Aboveground portions of all crops were removed, weighed, and samples taken for analysis. Total nitrogen and carbon in the soil, at varying depths and times and with different covercrops, was measured. Variation in yields of different covercrops under varying nitrogen applications were observed. 


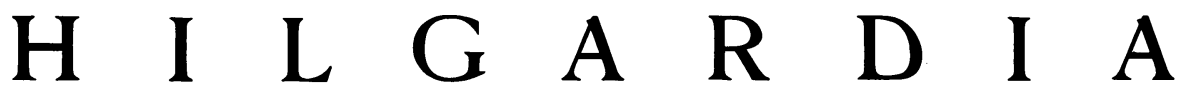 \\ A Journal of Agricultural Science Published by \\ the California Agricultural Experiment Station
}

\section{GAINS AND LOSSES OF MINERAL ELEMENTS IN AN IRRIGATED SOIL DURING A 20-YEAR LYSIMETER INVESTIGATION ${ }^{2}$}

\author{
P. F. PRATT ${ }^{2}$ and H. D. CHAPMAN ${ }^{3}$
}

\section{INTRODUCTION}

The MAIN OBJECTIVE in the investigation reported herein was to determine $\mathrm{N}$ gains and losses with various combinations of winter crops and fertilizer applications. A secondary objective was to determine the gains and losses of $\mathrm{Ca}, \mathrm{Mg}, \mathrm{Na}, \mathrm{K}, \mathrm{Cl}, \mathrm{S}$ and $\mathrm{P}$. Seven of these elements are essential for the growth of plants and the element $\mathrm{Na}$, although not essential for plants, is of interest as one of the detrimental components in salt-affected soils.

Chapman, Liebig and Rayner (1949) ${ }^{4}$ reported the $\mathrm{N}$ gains and losses during the first 10 years and Broadbent and Chapman (1950) reported data summarizing the first 15 years of the experiment. The purpose of this report is to present data for the complete experiment. Although some of the conclusions are the same as previously reported, the data for the last five years and a more complete analysis of the soil at the end of the experiment have added considerably to the value of the experiment. Enough new relationships and conclusions have emerged to justify an additional publication.

\section{DESCRIPTION OF THE EXPERIMENT}

Tanks and Soil. The tanks were made of 16-gauge galvanized iron. They were 10 feet in diameter and 4 feet deep with funnel-shaped bottoms. The tanks were filled with soil in 1926. An 8-inch layer of No. 3 flint rock, ranging in size from $3 / 8$ to $11 / 2$ inches in diameter, was placed in the bottom to provide a filter for the soil. The soil was taken from the surface foot of a virgin granitic-derived residual soil formerly classified as a Sierra loam

${ }^{1}$ Submitted for publication July 18, 1960.

${ }^{2}$ Associate Chemist, Department of Soils and Plant Nutrition, University of California, Riverside.

${ }^{3}$ Chairman and Professor of Soils and Plant Nutrition, University of California, Riverside.

The authors wish to acknowledge the contribution of R. L. Branson, F. T. Bingham, F. E. Broadbent, G. F. Liebig, D. S. Rayner, V. P. Sokoloff and W. P. Kelley to the progress of the experiment reported herein.

"See "Literature Cited" for citations referred to in text by author and date. 
but now classified as a Holland loam. From 1926 to 1933 the soil was unirrigated and clean cultivated so that vegetation was not allowed to grow. Soil samples were taken in 1933 and the experiment was started with a crop of barley in all tanks in the summer of 1934. Additional soil samples were taken in 1939, 1944, 1949, 1954.

Treatments. The treatments consisted of the application of cereal straw and the growth of vetch, melilotus and mustard covercrops, each in combination with 0,100 , and 200 pounds $\mathrm{N}$ per acre per year from $\mathrm{Ca}\left(\mathrm{NO}_{3}\right)_{2}$. Thus, there were twelve treatments and no true replication. The value of the experiment would have been increased by adding replicates. However, there was more than ample replication in years and there was replication in the sense that each $\mathrm{N}$ rate was applied to each of four crops or crop residue treatments.

The treatments described above were winter treatments. The $\mathrm{Ca}\left(\mathrm{NO}_{3}\right)_{2}$ was added to the winter crop and was applied at time of planting for the 100 pound rate, but for the 200 pound rate half was added at planting time and half was added at the time the covercrops were worked into the soil. The $\mathrm{Ca}\left(\mathrm{NO}_{3}\right)_{2}$ added with the straw was applied when the straw was spaded into the soil; straw was added at a rate of 500 pounds per acre per year. The summer crop which was grown uniformly in all tanks was barley from 1934 to 1939 inclusive and Sudangrass from 1940 to 1953 inclusive. The total of the aboveground portion of the plants of all crops was removed, weighed, and samples taken for analysis. The winter crops were returned to the soil but the summer crops were not returned and thus the summer crop was used to deplete the soil.

Irrigation Water. The irrigation water was fairly constant in composition during the 20 years of the experiment. The average mineral content was 2.43 me. Ca, 1.46 me. Na, 0.76 me. $\mathrm{Mg}, 0.63$ me. $\mathrm{Cl}, 1.03$ me. $\mathrm{SO}_{4}$, and $3.00 \mathrm{me}$. $\mathrm{HCO}_{3}{ }^{-}$per liter. The water was of good quality with a conductivity of 0.570 millimhos per $\mathrm{cm}$. and a $\mathrm{Na}$ content of 31 per cent. The water contains no residual $\mathrm{Na}_{2} \mathrm{CO}_{3}$, but assuming that all of the $\mathrm{HCO}_{3}{ }^{-}$was precipitated by $\mathrm{Ca}$ and $\mathrm{Mg}$, the $\mathrm{Na}$ content of the water would be 88 per cent.

Irrigation water was added in sufficient quantities to supply the needs of the crops. Leaching resulted from the application of irrigation water only once during the experiment. This occurred in the spring of 1939 when extra water was added to promote leaching and the removal of accumulated nitrates.

Rainfall. The average rainfall for the 20 years was 9.26 inches per year with annual variations from 5.45 to 22.47 inches. The rainfall came mostly in the winter months. During 10 of the 20 years leaching resulted from rainfall.

The average $\mathrm{N}$ content of the rain was 1.1 pounds per acre per year with variations from 0.2 to 2.3. The $\mathrm{Cl}$ and $\mathrm{S}$ contents of the rain of the 1953-54 season were 3.2 and 4.9 pounds per acre respectively. The total rainfall during the 1953-54 year was 9.14 inches. 


\section{RESULTS}

Yield and Nitrogen Content of Crops. Data for the average yield of dry matter of crops are presented in table 1 . There were small but consistent increases in yield of the annual legumes as a result of $\mathrm{N}$ applications. These increases in yields were certainly not economical and in no way justify the application of $\mathrm{N}$ to such crops. However, they do indicate that at some time in the growth of these crops $\mathrm{N}$ fixation by the legume nodule bacteria present was not sufficient to give maximum growth rate.

There were large increases in yield of mustard with increases in $\mathrm{N}$ fer-

TABLE 1

AVERAGE YIELD OF DRY MATTER OF WINTER CROPS FOR FOUR 5-YEAR PERIODS AND FOR WINTER AND SUMMER CROPS FOR THE TOTAL EXPERIMENT

\begin{tabular}{|c|c|c|c|c|c|c|c|}
\hline \multirow{2}{*}{ Crop } & \multirow{2}{*}{$\begin{array}{l}\text { Fertilizer } \\
\mathrm{Ca}\left(\mathrm{NO}_{3}\right)_{2}\end{array}$} & \multicolumn{5}{|c|}{ Winter crops } & \multirow{2}{*}{$\begin{array}{c}\text { Summer } \\
\text { crop* }^{*} \\
1934-1954\end{array}$} \\
\hline & & $1934-1939$ & $1939-1944$ & $1944-1949$ & $1949-1954$ & 1934-1954 & \\
\hline & lbs $N / A$ & $l b s / A$ & $l b s / A$ & $l b s / A$ & $l b s / A$ & $l b s / A$ & $l b s / A$ \\
\hline Straw. . & none & $\ldots$ & $\ldots$ & $\ldots$ & $\ldots$ & $\ldots$ & 7220 \\
\hline Straw .......... & 100 & $\ldots$ & $\ldots$ & $\ldots$ & $\ldots$ & $\ldots$ & 9170 \\
\hline Straw..................... & 200 & $\cdots$ & $\cdots$ & $\cdots$ & $\cdots$ & $\cdots$ & 8810 \\
\hline$\ldots \ldots \ldots \ldots \ldots$ & none & 3540 & 990 & 318 & 1220 & 1520 & 6820 \\
\hline Mustard........ & 100 & 4630 & 4240 & 3220 & 5000 & 4270 & 8700 \\
\hline Mustard..................... & 200 & 4720 & 5330 & 4040 & 5830 & 4980 & 8630 \\
\hline Vetch... & none & 5420 & 4220 & 5880 & 5170 & 5170 & 8120 \\
\hline Vetch......... & 100 & 5530 & 4640 & 6500 & 5750 & 5610 & 8120 \\
\hline Vetch.......... & 200 & 5690 & 4750 & 6760 & 5790 & 5750 & 8360 \\
\hline Melilotus... & none & 4630 & 3670 & 4470 & 3790 & 4140 & 8620 \\
\hline Melilotus................... & 100 & 4500 & 4570 & 5230 & 4720 & 4750 & 8530 \\
\hline Melilotus................... & 200 & 4720 & 4420 & 5500 & 5000 & 4900 & 8640 \\
\hline
\end{tabular}

* Summer crop was the same for all treatments.

tilizer except in the first five years when the soil contained a large amount of nitrate $\mathrm{N}$ accumulated from the 1926-34 fallow period.

The yield of the summer crop was increased by about a ton per year by applications of $\mathrm{N}$ where the winter treatment was mustard or straw. The $\mathrm{N}$ needed to produce these large yields of the summer crop, where no $\mathrm{N}$ was added, came mainly from decomposition of soil organic matter in the turned under mustard and straw. Temperature and moisture conditions were favorable during the summer for rapid mineralization of organic matter whereas in winter during the growth of the mustard crop the temperature was low enough that mineralization was extremely slow.

Where the winter crop was a legume there were no increases in yield of the summer crop as a result of $\mathrm{N}$ fertilization. Enough $\mathrm{N}$ was fixed by the legumes to fully meet the $\mathrm{N}$ requirements of the summer crop.

The relation between the average $\mathrm{N}$ in tops of plants of winter crops and the annual rate of application of $\mathrm{N}$ to the soils as $\mathrm{Ca}\left(\mathrm{NO}_{3}\right)_{2}$ for the last 15 


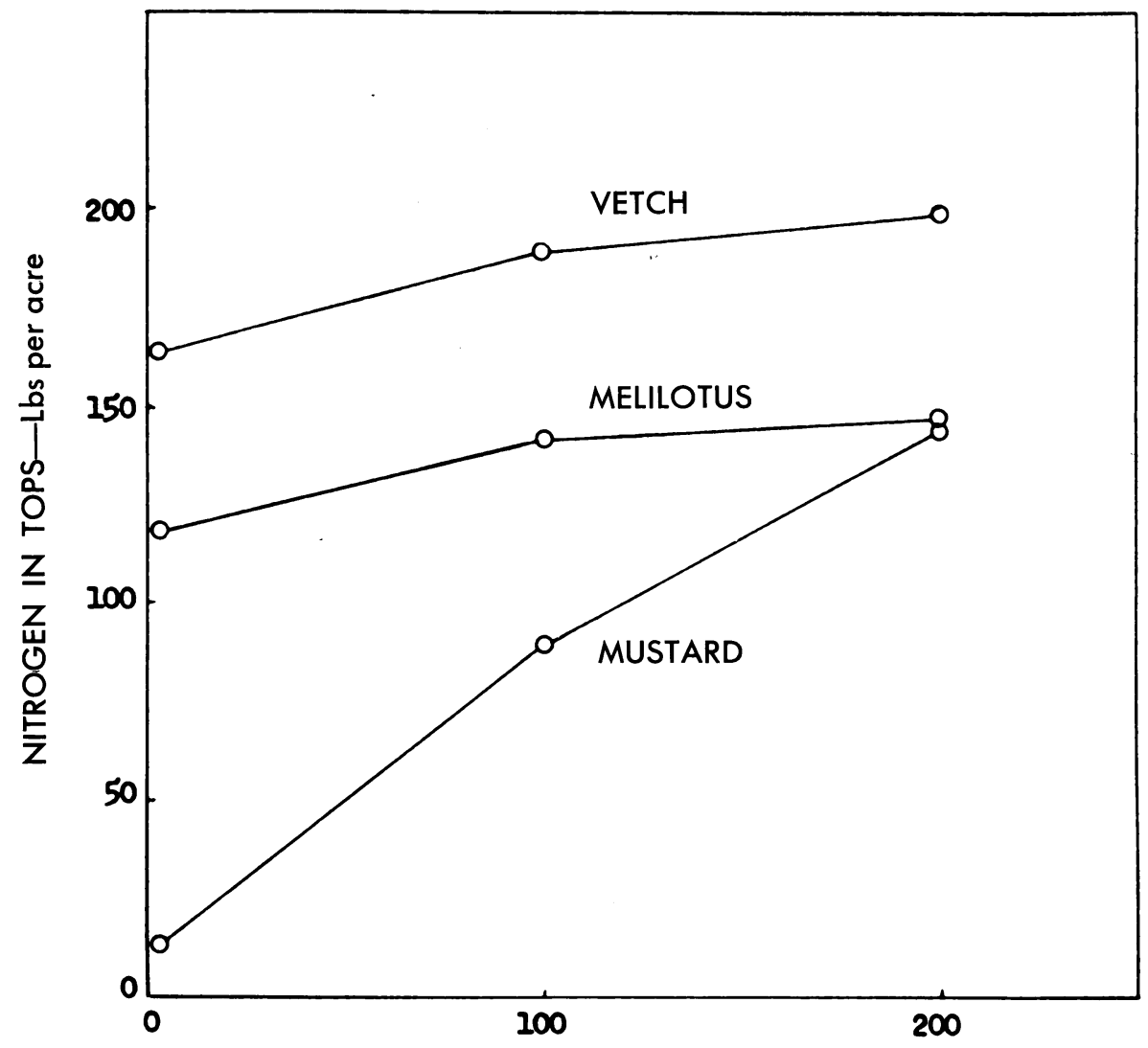

\section{NITROGEN ADDED—Lbs per acre}

Fig. 1. Relation between average $\mathrm{N}$ in tops of plants in last 15 years of the experiment and the annual rate of application of $\mathrm{N}$ as $\mathrm{Ca}\left(\mathrm{NO}_{3}\right)_{2}$.

years of the experiment is presented in figure 1 . The first 5 years' data were not used in this case because of the high nitrate-N content of the soil during that period. The $\mathrm{N}$ in the mustard crop with no $\mathrm{N}$ added was about 12 pounds per acre per year. This is not much greater than the $\mathrm{N}$ in the rain plus that in the irrigation water. Thus, practically no $\mathrm{N}$ was released from the soil during the growth of this crop. When $\mathrm{N}$ was added to the soil the apparent recovery by mustard was about 80 per cent at the 100 -pound rate and about 70 per cent a the 200-pound rate.

Both of the legume crops showed increased $\mathrm{N}$ in tops with increased amounts of $\mathrm{N}$ added to the soil. Using calculated $\mathrm{N}$ fixation data (see section on Nitrogen Gains and Losses) to correct for contributions from the nodule bacteria the apparent $\mathrm{N}$ recovery by the vetch was 52 and 90 pounds per acre per year or 52 and 45 per cent for $\mathrm{N}$ at the 100- and 200-pound rate respectively. Corresponding data for melilotus were 72 and 47 per cent recovery. 


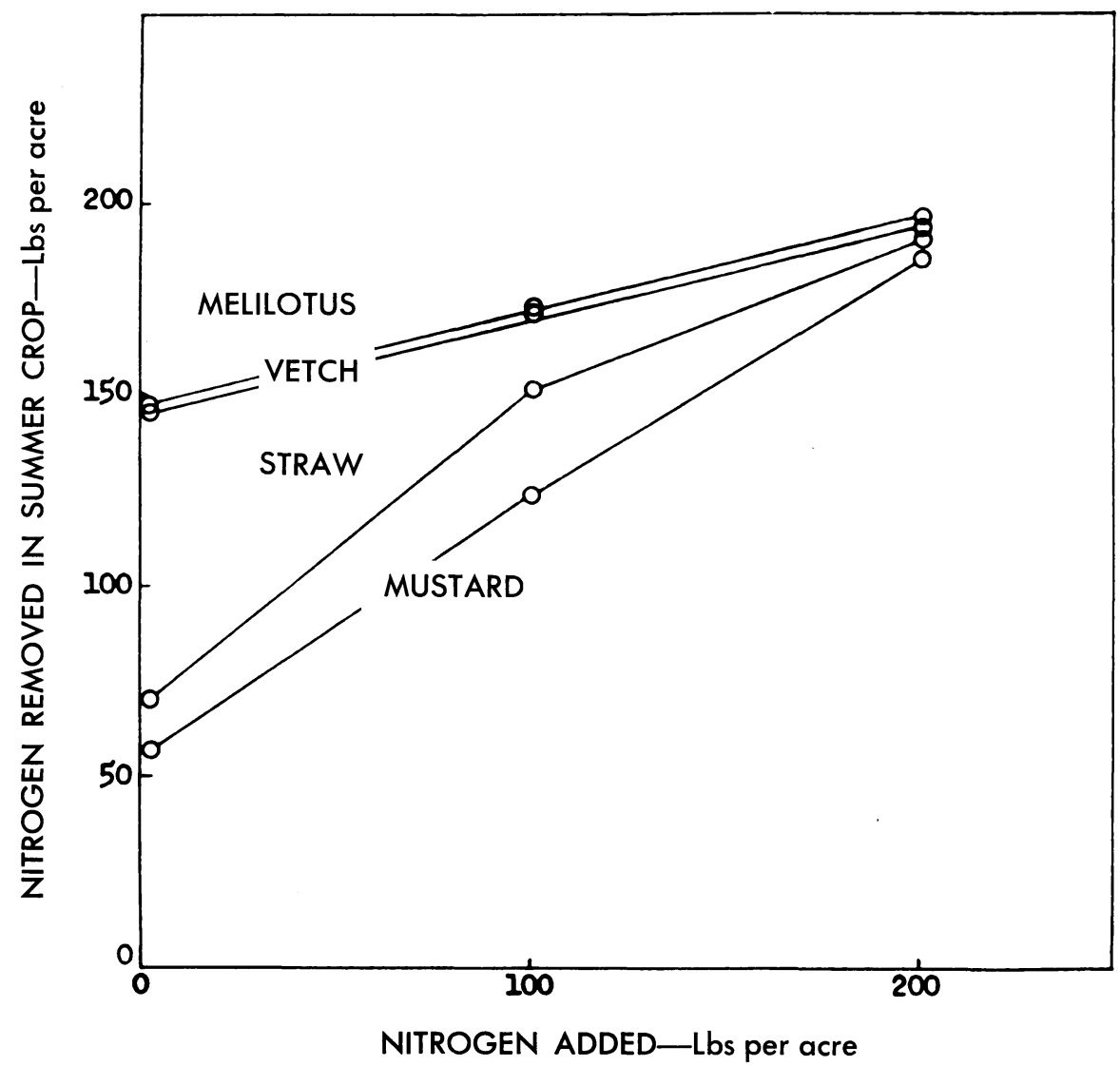

Fig. 2. Relation between average $\mathrm{N}$ removed in summer crop during last 15 years of the experiment and the annual rate of application of $\mathrm{N}$ as $\mathrm{Ca}\left(\mathrm{NO}_{3}\right)_{2}$.

Figure 2 presents the relation between the average $\mathrm{N}$ removed in the summer crop and the annual rate of application of $\mathrm{N}$ as $\mathrm{Ca}\left(\mathrm{NO}_{3}\right)_{2}$. $\mathrm{Al}$ though the rate of application of $\mathrm{Ca}\left(\mathrm{NO}_{3}\right)_{2}$ had only a small effect on yields of the summer crop it had a large effect on $\mathrm{N}$ removal, particularly with the straw and mustard winter treatments. Yield increases were only about 25 per cent whereas increases in $\mathrm{N}$ removal were increased about threefold.

Vetch and melilotus without $\mathrm{N}$ were 75 per cent as effective as mustard with the highest rate of $\mathrm{N}$ in supplying $\mathrm{N}$ to the summer crop. Comparing the legumes with mustard the legumes alone were equivalent to mustard plus 135 pounds of $\mathrm{N}$ from fertilizer. This agrees well with $\mathrm{N}$ fixation data of 131 and 124 pounds $\mathrm{N}$ per acre per year for vetch and melilotus respectively.

Nitrogen. Data on the gains and losses of $\mathrm{N}$ in soil for four 5-year periods and for the total period of the lysimeter experiment, and the total gains and losses as a percentage of the total $\mathrm{N}$ in the soil at the beginning of the experiment are presented in table 2. These data represent the sum of the 
additions from seed, rain, irrigation water, fertilizer, and straw, plus release from the soil subtracted from the sum of the removals in crops and leachate. The difference, if positive, represents an increase in $\mathrm{N}$ and is assumed to be a fixation from atmospheric $\mathrm{N}$; if negative, it is assumed to be a volatilization loss of added $\mathrm{N}$. The contribution from the soil was calculated from a determination of total $\mathrm{N}$ of soil samples taken in June of 1933, 1939, 1944, 1949, and 1954.

The data for the vetch and melilotus cover crops are positive and thus indicate a fixation of $\mathrm{N}$ by these crops. Total fixation in the 20 -year period

TABLE 2

GAINS AND LOSSES OF N IN SOILS FOR FOUR 5-YEAR PERIODS AND FOR THE TOTAL PERIOD OF A LYSIMETER EXPERIMENT, AND TOTAL GAINS AND LOSSES AS PERCENTAGES OF TOTAL N IN THE SOIL AT THE BEGINNING OF THE EXPERIMENT

\begin{tabular}{|c|c|c|c|c|c|c|c|}
\hline \multicolumn{2}{|l|}{ Treatment } & \multicolumn{5}{|c|}{ Nitrogen gains or losses in soil* } & \multirow{2}{*}{$\begin{array}{c}\text { Total } \\
\text { gain or loss } \\
\mathrm{N} \text { in soil }\end{array}$} \\
\hline Crop material or covercrop & $\begin{array}{l}\text { Calcium } \\
\text { Nitrate }\end{array}$ & $1934-1939$ & $1939-1944$ & $1944-1949$ & 1949-1954 & Total & \\
\hline & lbs $N / A$ & $l b s / A$ & $l b s / A$ & $l b s / A$ & $l b s / A$ & $l b s / A$ & per cent \\
\hline Cereal straw.... & $\mathbf{0}$ & -128 & 240 & 83 & -112 & 83 & 1.2 \\
\hline Cereal straw.................. & 100 & -171 & 131 & -141 & 212 & 31 & 0.4 \\
\hline 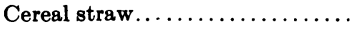 & 200 & -261 & -189 & -36 & 350 & -136 & -1.9 \\
\hline Mustard covercrop & 0 & -228 & 199 & 82 & -227 & -174 & -2.5 \\
\hline Mustard covercrop ..... & 100 & -319 & 226 & -49 & 234 & 92 & 1.3 \\
\hline Mustard covercrop $\ldots \ldots \ldots \ldots \ldots$ & 200 & -206 & -317 & -24 & 244 & -303 & -4.3 \\
\hline Vetch covercrop & $\mathbf{0}$ & 315 & 741 & 835 & 738 & 2629 & 37.6 \\
\hline Vetch covercrop & 100 & 345 & 684 & 115 & 971 & 2115 & 30.8 \\
\hline Vetch covercrop ... & 200 & 248 & 429 & 535 & 327 & 1539 & 22.0 \\
\hline Melilotus covercrop ... & 0 & 348 & 833 & 825 & 466 & 2472 & 35.4 \\
\hline Melilotus covercrop $\ldots \ldots \ldots \ldots$ & 100 & 115 & 386 & 410 & 737 & 1648 & 23.5 \\
\hline Melilotus covercrop $\ldots \ldots \ldots \ldots$ & 200 & 224 & 150 & 728 & 243 & 1345 & 19.2 \\
\hline
\end{tabular}

* Nitrogen fixation if positive and volatilization if negative.

averaged 131, 106, and 77 pounds per acre per year, respectively, for vetch at 0,100 , and 200 pounds $\mathrm{N}$ per acre per year. Total fixation by melilotus averaged 124, 82, and 67 pounds per acre per year, respectively for the same rates of $\mathrm{N}$ applications. These data are sufficiently large and so consistently positive that there should be no question about their significance.

Variations in $\mathrm{N}$ fixation by legumes in the four 5-year periods are relatively large. These variations are not associated with yields or with any environmental or soil factors that were measured but appear to be random with no interaction between periods and $\mathrm{N}$ fixation.

The data for the total experiment suggest no significant gains or losses of $\mathrm{N}$ for either the straw or the mustard covercrop treatments. The largest positive value of the total $\mathrm{N}$ in the soil at the beginning of the experiment is 1.3 per cent, and the largest negative value is 4.3 per cent. In contrast, the smallest value for $\mathrm{N}$ fixation with legumes was 19.2 per cent of the total 
$\mathrm{N}$ in the soil. Thus, on the average, with straw or mustard there was neither a net fixation nor a net volatilization of nitrogen during the 20 years of the experiment. There were variations among the data for the four 5-year periods but these variations appeared to be random and not associated or correlated with periods or with the environmental factors that were measured.

Since the increase or decrease in total soil $\mathrm{N}$ enters into all the calculations of gains or losses of $\mathrm{N}$, one must consider the gains or losses of $\mathrm{N}$ in relation to the errors involved in measuring the total soil $\mathrm{N}$ in the tanks. The original total soil $\mathrm{N}$ was about 7,000 pound per acre. Chapman, Liebig and Rayner (1949), in discussing the first 10 years of the experiment, estimated that differences of greater than 150 to 200 pounds $\mathrm{N}$ per acre from one sampling period to the next would be real. Broadbent and Chapman (1950), however, found that variations in the 1949 soil samples were such that values as great as 320 pounds per acre might not be significant at the 5 per cent level of probability. The 320 pounds $\mathrm{N}$ per acre represent 4.6 per cent of the original $\mathrm{N}$ content of the soil. The values for total $\mathrm{N}$ gains or losses with the mustard and cereal straw treatments are less than this value and are thus likely to be non-significant.

In this experiment there was no evidence of reducing conditions in the soils. Drainage water was always free of reduced forms of Fe and Mn. (Data obtained recently from filled-in lysimeters containing 5.5 feet of soil show that when reducing conditions are attained the drainage water may contain as much as $12 \mathrm{ppm}$. Mn and $8 \mathrm{ppm}$. Fe, and that when exposed to the air, these elements are oxidized and precipitated as oxides.) Thus the absence of volatilization losses of $\mathrm{N}$ can be attributed to lack of reducing conditions in the soil. However, there is also the possibility that losses did take place and that these were balanced by nonsymbiotic $\mathrm{N}$ fixation.

If the $\mathrm{N}$ gains and losses with the non-legume treatments, expressed as percentages of the total $\mathrm{N}$ in the soil, are used as estimates of experimental error, they indicate that the experiment was well conducted, that no gross errors were involved, and that all samples of water, soil, plants, and leachate were representative of the totals of these materials in the experiment.

The data show that relatively large amounts of $\mathrm{N}$ can be fixed by annual winter legume crops and that the maximum fixation is obtained when the soil contains a low supply of available $\mathrm{N}$. The $\mathrm{N}$ fixation is also dependent on the growth of the legume crop. In the lysimeters the dry weight yields were relatively large and thus conditions were extremely favorable for $\mathrm{N}$ fixation.

One might expect similar quantities of fixation in the field only if similar favorable conditions are found. Where shading, drought, salinity, nutrient deficiencies or other soil or environmental factors limit yields, or where the soil is supplied with available $\mathrm{N}$, the fixation may be reduced to a small fraction of the values reported here.

The data for the cereal straw treatments and the mustard covercrop suggest that volatilization losses of $\mathrm{N}$ are not serious where care is taken to avoid waterlogging the soil and that the usual irrigation practices on soils that are internally well drained do not produce volatilization. Thus, the usual mechanism of $\mathrm{N}$ depletion are crop removal and leaching losses. It is well 
established, however, that volatilization does take place when reducing conditions are established by prolonged saturation of the soil with water.

The foregoing statements apply to neutral and alkaline soils fertilized with $\mathrm{Ca}\left(\mathrm{NO}_{3}\right)_{2}$. There is evidence from other sources that there can be $\mathrm{N}$ volatilization losses from acid or alkaline soils fertilized with urea and ammonium sources of $\mathrm{N}$ under normal aerobic conditions. Allison (1955) in a review of the literature dealing with $\mathrm{N}$ gains and losses in lysimeters and in field trials reported that most experiments show an unaccounted-for loss of $\mathrm{N}$ which is assumed to be loss by volatilization. The absence of loss

TABLE 3

POTASSIUM ADDED AND REMOVED AND DEPLETION FROM THE SOILS DURING 20 YEARS

\begin{tabular}{|c|c|c|c|c|c|c|}
\hline \multicolumn{2}{|c|}{ Treatment } & \multirow{2}{*}{$\begin{array}{l}\text { Potassium } \\
\text { added }^{*}\end{array}$} & \multicolumn{3}{|c|}{ Potassium removed } & \multirow{2}{*}{$\begin{array}{c}\text { Depletion } \\
\text { of soil }\end{array}$} \\
\hline \multirow[t]{2}{*}{ Winter crop } & $\mathrm{Ca}\left(\mathrm{NO}_{3}\right)_{2}$ & & Crop & Leaching & Total & \\
\hline & lbs $N / A$ & $l b s / A$ & $l b s / A$ & $l b s / A$ & $l b s / A$ & $l b s / A$ \\
\hline Straw. & none & 1721 & 3418 & 20 & 3438 & 1717 \\
\hline Straw........... & 100 & 1726 & 4376 & 33 & 4409 & 2683 \\
\hline Straw............. & 200 & 1725 & 4701 & 50 & 4751 & 3026 \\
\hline Mustard.. & none & 198 & 3208 & 23 & 3231 & 3033 \\
\hline Mustard... & 100 & 235 & 4483 & 25 & 4508 & 4273 \\
\hline Mustard... & 200 & 237 & 4853 & 16 & 4869 & 4632 \\
\hline Vetch. & none & 239 & 3880 & 15 & 3895 & 3656 \\
\hline Vetch. . & 100 & 245 & 4021 & 22 & 4043 & 3798 \\
\hline Vetch. & 200 & 247 & 4476 & 25 & 4501 & 4254 \\
\hline Melilotus. & none & 230 & 4013 & 31 & 4044 & 3814 \\
\hline Melilotus.. & 100 & 232 & 4382 & 34 & 4422 & 4190 \\
\hline Melilotus. & 200 & 234 & 4581 & 36 & 4617 & 4383 \\
\hline Averag & & 606 & 4199 & 28 & 4227 & 3621 \\
\hline
\end{tabular}

* Potassium added in water except for $1574 \mathrm{lb} . \mathrm{K}$ per acre added in straw.

of $\mathrm{N}$ in this experiment might be attributed to the alkaline conditions of the soil combined with a nitrate source of $\mathrm{N}$.

Phosphorus. There was little if any $\mathrm{P}$ added in irrigation water or in fertilizer or straw. Also, the drainage water had little if any $P$. Thus the $\mathrm{P}$ removed by cropping represented depletion. The average removed by crops was 317 pounds per acre for the 20-year period, or 15.9 pounds per acre per year.

Potassium. Data for the $\mathrm{K}$ added and removed and depletion from the soil are presented in table 3 . The average depletion was 181 pounds $\mathrm{K}$ per acre per year mostly by crop removal. Very little $\mathrm{K}$ was lost by leaching and only a relatively small amount was added in the irrigation water.

Magnesium. Data for gains and losses of $\mathrm{Mg}$ are presented in table 4 . The Mg added was mostly added in the irrigation water. Removal was about equally distributed between crop removal and leaching. Within each winter crop or crop residue treatment there was a decrease in $\mathrm{Mg}$ accumulation or an increase in $\mathrm{Mg}$ loss with increase in rate of application of $\mathrm{Ca}\left(\mathrm{NO}_{3}\right)_{2}$. 
TABLE 4

GAINS AND LOSSES OF MAGNESIUM DURING THE 20 YEARS OF THE LYSIMETER EXPERIMENT

\begin{tabular}{|c|c|c|c|c|c|c|}
\hline \multicolumn{2}{|l|}{ Treatment } & \multirow{2}{*}{$\begin{array}{l}\text { Magnesium } \\
\text { added* }^{*}\end{array}$} & \multicolumn{3}{|c|}{ Magnesium removed } & \multirow{2}{*}{$\begin{array}{l}\text { Added } \\
\text { minus } \\
\text { removal }\end{array}$} \\
\hline Winter crop & $\mathrm{Ca}\left(\mathrm{NO}_{3}\right)_{2}$ & & Crop & Leaching & Total & \\
\hline & $l b s / A$ & $l b s / A$ & $l b s / A$ & $l b s / A$ & $l b s / A$ & $l b s / A$ \\
\hline Straw.... & none & 780 & 307 & 508 & 815 & -35 \\
\hline Straw . . . . . . . . & 200 & 808 & 582 & 750 & 1332 & -524 \\
\hline Mustard. & none & 938 & 325 & 428 & 753 & 185 \\
\hline Mustard... & 100 & 1080 & 546 & 394 & 940 & 140 \\
\hline Mustard... & 200 & 1100 & 634 & 383 & 1017 & 83 \\
\hline Melilotus. & none & 1060 & 594 & 412 & 1006 & 54 \\
\hline Melilotus. & 100 & 1060 & 624 & 491 & 1115 & -55 \\
\hline Melilotus. & 200 & 1070 & 647 & 635 & 1282 & -212 \\
\hline Average.. & & 1004 & 550 & 489 & 1039 & -35 \\
\hline
\end{tabular}

* Magnesium in the irrigation water except $90 \mathrm{lbs} / \mathrm{A}$ added in straw.

TABLE 5

SODIUM ADDED, REMOVED BY CROPPING AND LEACHING, ACCUMULATION IN THE SOIL AND REMOVAL AS A PERCENTAGE OF TOTAL ADDED

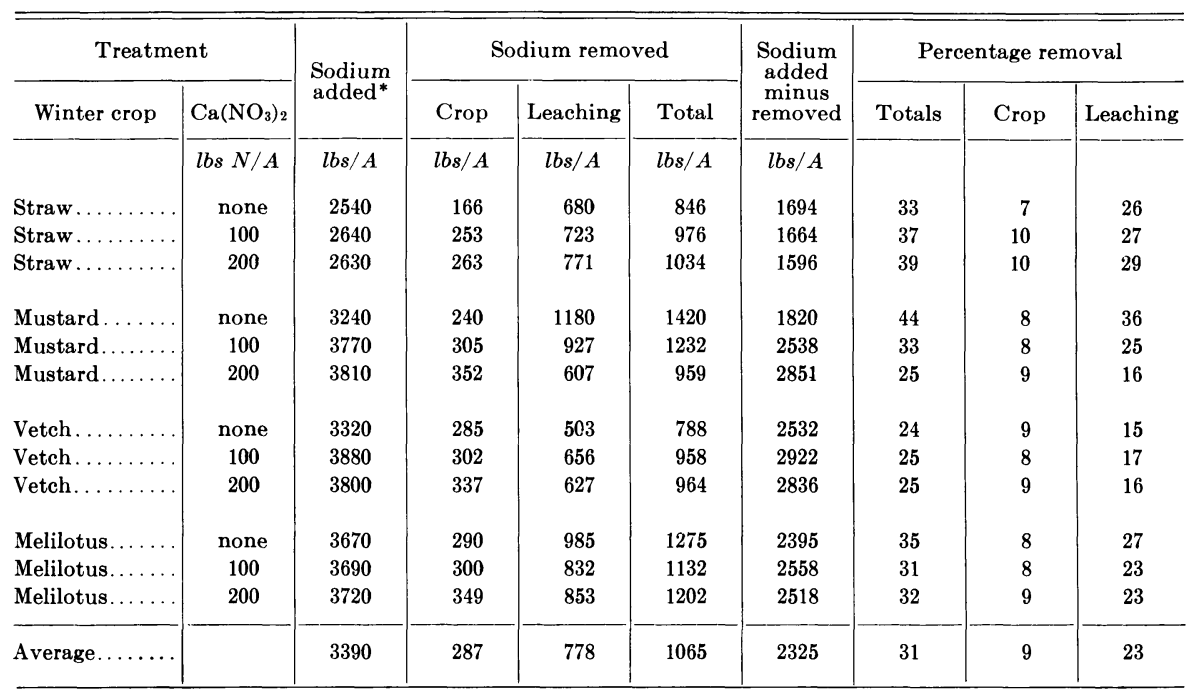

\footnotetext{
* Sodium added was in the irrigation water except for $135 \mathrm{lbs} / \mathrm{A}$ added in the straw.
} 
TABLE 6

GAINS AND LOSSES OF Cl AND PERCENTAGE REMOVAL OF ADDED Cl by CROPS AND BY LEACHING

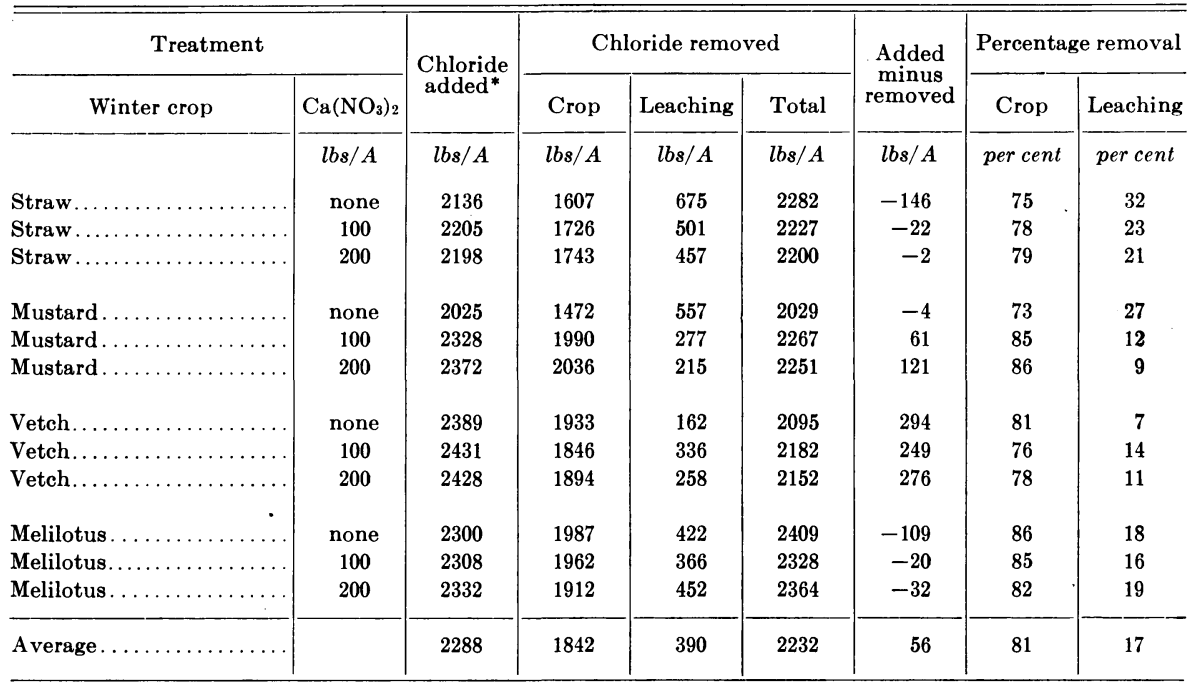

* Chloride added was from the irrigation water except for $629 \mathrm{lbs} / \mathrm{A}$ added in straw.

TAELE 7

GAINS, LOSSES, AND ACCUMULATION OF CALCIUM IN LYSIMETERS DURING 20 YEARS OF TREATMENT AND THE $\mathrm{CaCO}_{3}$ DETERMINED IN THE SOIL AFTER THE 20-YEAR PERIOD

\begin{tabular}{|c|c|c|c|c|c|c|c|c|c|}
\hline \multicolumn{2}{|c|}{ Winter treatment } & \multicolumn{8}{|c|}{$\mathrm{CaCO}_{3}$ equivalent of $\mathrm{Ca}$, lbs. per acre } \\
\hline $\begin{array}{c}\mathrm{Ca}\left(\mathrm{NO}_{3}\right)_{2} \\
\text { lbs. } \mathrm{N} \\
\text { per acre }\end{array}$ & $\begin{array}{c}\text { Crop or } \\
\text { crop material* }\end{array}$ & $\begin{array}{c}\text { Irriga- } \\
\text { tion } \\
\text { water }\end{array}$ & $\begin{array}{l}\text { Fertilizer } \\
\text { and } \\
\text { straw }\end{array}$ & $\begin{array}{l}\text { Total } \\
\text { added }\end{array}$ & $\begin{array}{c}\text { Removal } \\
\text { in } \\
\text { summer } \\
\text { crop }\end{array}$ & $\begin{array}{c}\text { Removal } \\
\text { in } \\
\text { leachate }\end{array}$ & $\begin{array}{c}\text { Total } \\
\text { removal }\end{array}$ & $\begin{array}{l}\text { Added } \\
\text { minus } \\
\text { removal }\end{array}$ & $\begin{array}{c}\mathrm{CaCO}_{3} \\
\text { deter- } \\
\text { mined } \\
\text { in soil } \\
(1954)\end{array}$ \\
\hline 0 & Cereal straw.. & 8,960 & 740 & 9,700 & 2,130 & 4,620 & 6,750 & 2,950 & 4,030 \\
\hline $\mathbf{0}$ & Vetch. & 14,260 & 0 & 14,260 & 2,760 & 2,910 & 5,670 & 8,590 & 7,500 \\
\hline $\mathbf{0}$ & Melilotus. & 13,760 & 0 & 13,760 & 2,880 & 3,860 & 6,740 & 7,020 & 7,200 \\
\hline 0 & Mustard... & 12,140 & 0 & 12,140 & 1,980 & 4,040 & 6,020 & 6,120 & 5,710 \\
\hline 100 & Cereal straw. & 9,360 & 7,520 & 16,860 & 2,920 & 5,400 & 8,320 & 8,540 & 8,250 \\
\hline 100 & Vetch. & 14,520 & 6,780 & 21,300 & 2,910 & 4,730 & 7,640 & 13,660 & 12,600 \\
\hline 100 & Melilotus.. & 13,780 & 6,780 & 20,560 & 2,940 & 4,330 & 7,270 & 13,290 & 11,100 \\
\hline 100 & Mustard... & 14,070 & 6,780 & 20,850 & 2,790 & 3,690 & 6,480 & 14,370 & 15,450 \\
\hline 200 & Cereal straw. & 9,300 & 14,300 & 23,600 & 3,130 & 7,370 & 10,500 & 13,100 & 8,400 \\
\hline 200 & Vetch.... & 14,560 & 13,560 & 28,120 & 3,330 . & 5,430 & 8,760 & 19,360 & 13,800 \\
\hline 200 & Melilotus...... & 13,900 & 13,560 & 27,460 & 3,220 & 5,830 & 9,050 & 18,410 & 13,200 \\
\hline \multirow[t]{2}{*}{200} & Mustard....... & 14,200 & 13,560 & 27,760 & 3,130 & 3,570 & 6,710 & 21,050 & 19,400 \\
\hline & Average.. & & & 19,700 & 2,840 & 4,650 & 7,490 & 12,200 & 10,550 \\
\hline
\end{tabular}

* Winter crops were not removed from tanks. 


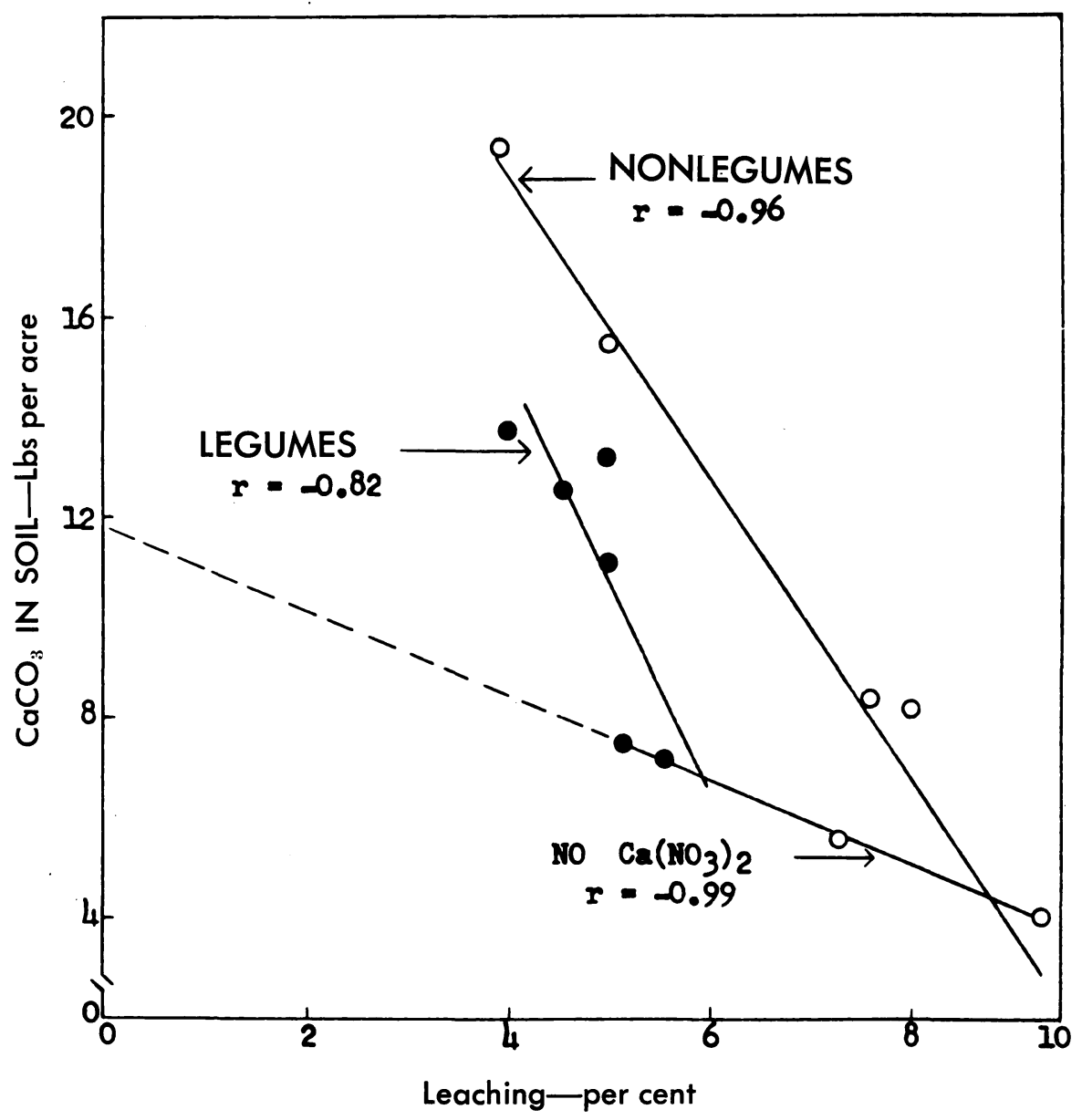

Fig. 3. Relations between $\mathrm{CaCO}_{3}$ accumulation in the soil and leaching as a per cent of total irrigation water added for non-legumes, legumes and no $\mathrm{Ca}\left(\mathrm{NO}_{3}\right)_{2}$ treatments.

This relationship between $\mathrm{Mg}$ loss from the soil and amount of salts added as fertilizer is the same as reported by Pratt and Harding (1957) for the soil of a long-term fertility trial.

The losses of $\mathrm{Mg}$ by leaching were increased by increases in $\mathrm{Ca}\left(\mathrm{NO}_{3}\right)_{2}$ except in the case of the mustard winter crop, where the $\mathrm{Ca}\left(\mathrm{NO}_{3}\right)_{2}$ applications, because of increased growth of the crop, reduced the amount of leachate from 7.3 per cent with no $\mathrm{N}$ applied to 3.9 per cent with 100 pounds $\mathrm{N}$ per acre. In all cases there were increases in $\mathrm{Mg}$ removal by cropping with increases in $\mathrm{Ca}\left(\mathrm{NO}_{3}\right)_{2}$. This effect was greatest with the straw and mustard winter treatments.

Sodium. Data for Na added, removed by cropping and leaching, accumulation in the soil, and that removed as a percentage of the total added, are 


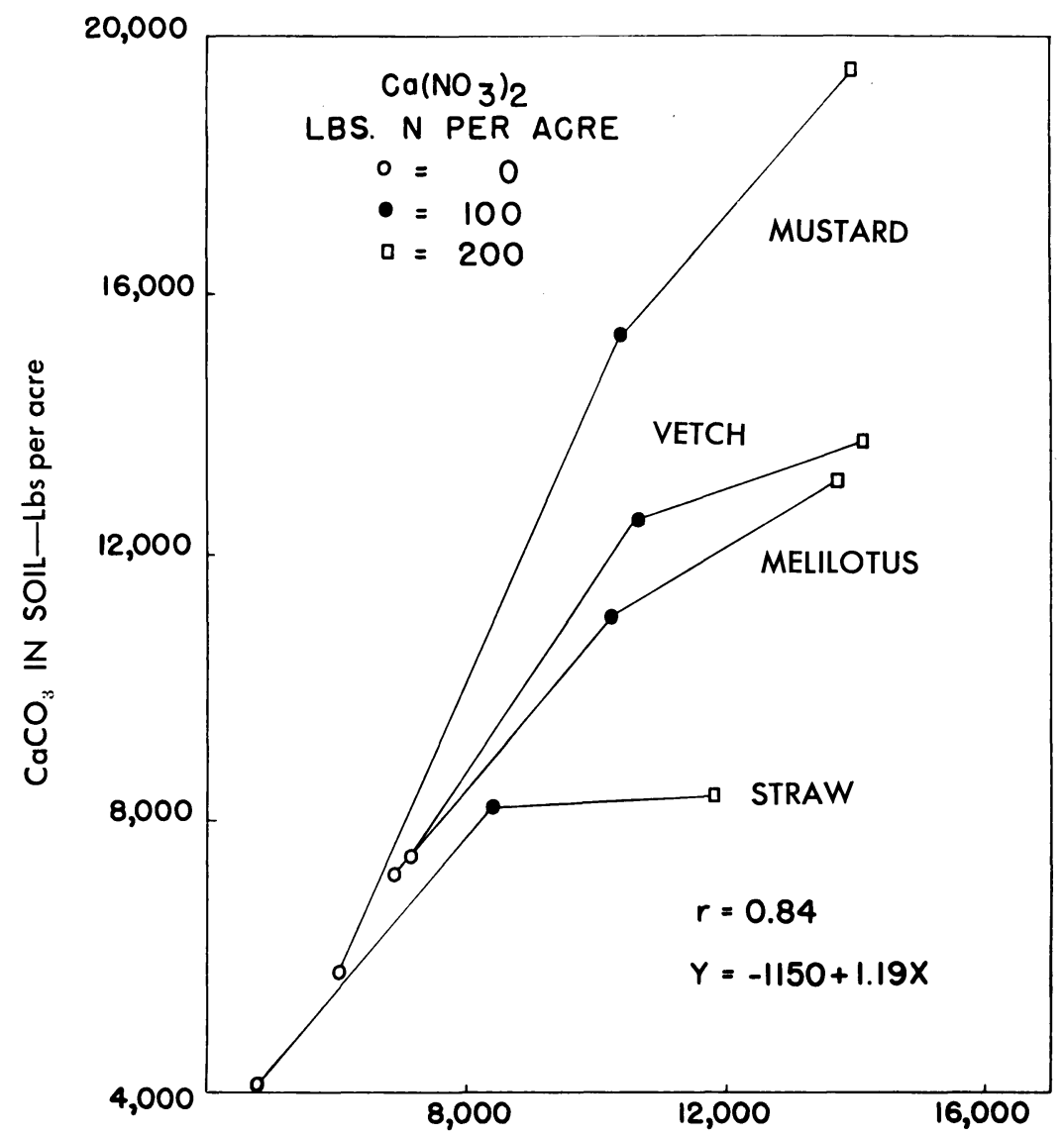

$\mathrm{CaCO}_{3}$ EQUIV. OF TOTAL Ca ADDED/2 - Lbs per acre

Fig. 4. Relationship between $\mathrm{CaCO}_{3}$ in the soil and the $\mathrm{CaCO}_{3}$ equivalent of half the total $\mathrm{Ca}$ added to the lysimeters in 20 years.

presented in table 5 . The $\mathrm{Na}$ accumulation averaged 69 per cent of that added.

About 85 per cent of the $\mathrm{Na}$ removed by crops was removed by the six crops of barley. If barley had been continued as the summer crop the removal of $\mathrm{Na}$ would have been about 55 per cent of the total added.

Chloride. Data for the gains and losses of $\mathrm{Cl}$ and the percentage removal of added $\mathrm{Cl}$ by crops and by leaching are presented in table 6 . Both barley and Sudan grass removed relatively large quantities of $\mathrm{Cl}$ and as a result the major portion of the $\mathrm{Cl}$ removed was removed by the summer crops. The average accumulation was only 2 per cent of that added.

Sulfur. The average $\mathrm{S}$ added to the tanks in 20 years was 1,700 pounds per acre. Of this 290 pounds was removed by crops, 1,070 pounds was removed by leaching and 337 pounds accumulated in the soil. The range of values for accumulation was from 898 to a -128 pounds per acre. The aver- 
age $\mathrm{S}$ accumulation per acre per year was 16.8 pounds, which is not a large yearly accumulation considering the fact that crop removal was small and leaching occurred during only half of the 20 years of the experiment.

Calcium. Data for gains, losses and accumulation of Ca during the experiment and the $\mathrm{CaCO}_{3}$ determined in the soil at the end of the experiment are presented in table 7 . For all treatments over the 20-year period the average $\mathrm{Ca}$ added minus the average removed was 12,300 pounds $\mathrm{CaCO}_{3}$ equivalent per acre. The average $\mathrm{CaCO}_{3}$ in the soil at the end of the ex-

TABLE 8

THE $\mathrm{CaCO}_{3}$ EQUIVALENT OF THE $\mathrm{HCO}_{3}{ }^{-}$ADDED IN THE IRRIGATION AND THE $\mathrm{CaCO}_{3}$ IN THE SOIL AS A PER CENT OF THE $\mathrm{HCO}_{3}^{-}$ADDED

\begin{tabular}{|c|c|c|c|}
\hline \multicolumn{2}{|r|}{ Winter treatment } & \multirow{2}{*}{$\begin{array}{c}\mathrm{CaCO}_{3} \text { equiva- } \\
\text { lent of } \mathrm{HCO}_{3}^{-} \\
\text {added in } \\
\text { irrigation water* } \\
\text { lbs/A }\end{array}$} & \multirow{2}{*}{$\begin{array}{l}\mathrm{CaCO}_{3} \text { in soil } \\
\text { as per cent of } \\
\mathrm{HCO}_{3} \text {-added }\end{array}$} \\
\hline $\begin{array}{l}\mathrm{Ca}\left(\mathrm{NO}_{3}\right)_{2} \\
\text { lbs/acre }\end{array}$ & Crop or crop material & & \\
\hline 0 & Straw ..... & 11,050 & 36.5 \\
\hline 0 & Vetch.......... & 17,600 & 42.6 \\
\hline 0 & 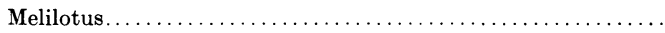 & 17,000 & 42.3 \\
\hline \multirow[t]{2}{*}{0} & 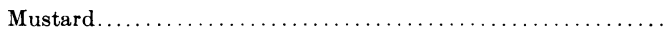 & 15,000 & 38.1 \\
\hline & Average.. & & 39.9 \\
\hline 100 & Straw...... & 11,550 & 71.4 \\
\hline 100 & Vetch... & 17,950 & 70.2 \\
\hline 100 & Melilotus.. & 17,030 & 65.2 \\
\hline \multirow[t]{2}{*}{100} & Mustard.. & 17,400 & 89.0 \\
\hline & Average. & & 74.0 \\
\hline 200 & Straw. & 11,500 & 73.2 \\
\hline 200 & Vetch. & 17,650 & 78.2 \\
\hline 200 & Melilotus..... & 17,200 & 76.8 \\
\hline \multirow[t]{2}{*}{200} & 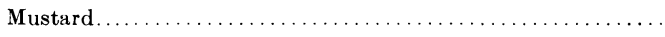 & 17,510 & 111.0 \\
\hline & Average... & & 84.8 \\
\hline
\end{tabular}

* Assuming the reaction is $\mathrm{Ca}^{++}+2 \mathrm{HCO}_{3}{ }^{-}=\mathrm{CaCO}_{3}+\mathrm{H}_{2} \mathrm{O}+\mathrm{CO}_{2}$.

periment was 10,550 pounds per acre, which is 86 per cent of the Ca that accumulated in the soil. The other 14 per cent was probably used to bring the $\mathrm{pH}$ of the soil from slightly acid to values between 7.8 and 8.3. The correlation coefficient for the relationship between $\mathrm{Ca}$ accumulation and $\mathrm{Ca}$ determined as $\mathrm{CaCO}_{3}$ in the soil was +0.92 , thus indicating that the $\mathrm{CaCO}_{3}$ precipitation was highly associated with, and most likely a function of, the Ca accumualtion.

The relations between $\mathrm{CaCO}_{3}$ accumulation in the soil and leaching percentage for the non-legume, legume and no $\mathrm{Ca}\left(\mathrm{NO}_{3}\right)_{2}$ treated tanks are presented in figure 3 . The mustard winter crop produced a greater $\mathrm{CaCO}_{3}$ precipitation than the legume crops at the same leaching percentage. The cause of the difference is not apparent but might have been caused by a greater drying of the soil during the autumn when the winter crops were becoming established. The mustard, particularly when fertilized with 


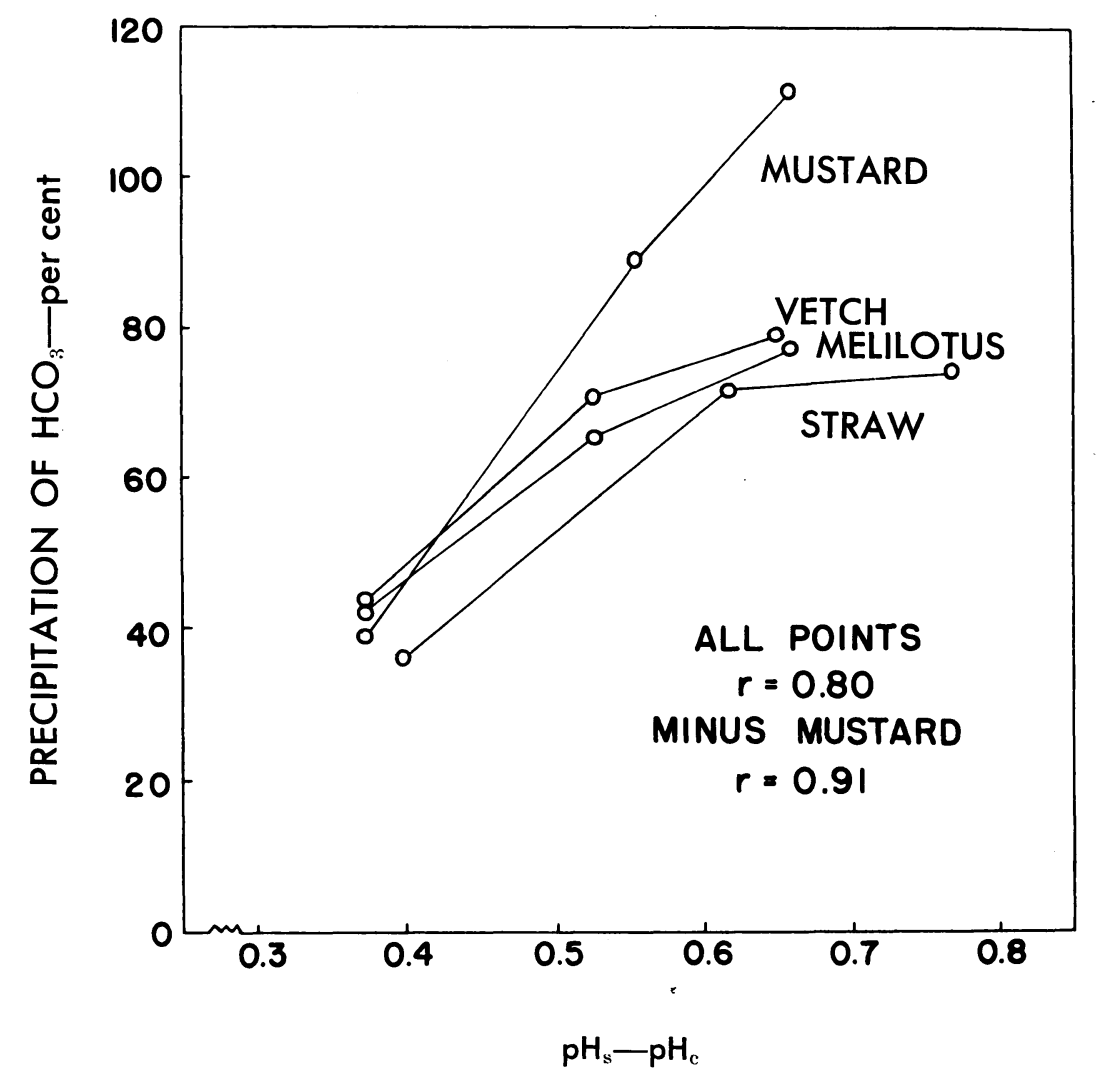

Fig. 5. Relation between per cent precipitation of the $\mathrm{HCO}_{3}^{-}$added in irrigation water and the difference between the measured $\mathrm{pH}$ of the paste and the $\mathrm{pH}$ that would be found in an equilibrium solution with $\mathrm{CaCO}_{3}$ at the $\mathrm{HCO}_{3}^{-}$and adjusted Ca content of the irrigation water.

$\mathrm{Ca}\left(\mathrm{NO}_{3}\right)_{2}$ grew much faster in the early season than the slow-starting legumes.

The Y-intercept value for the regression for the four tanks that received no $\mathrm{Ca}\left(\mathrm{NO}_{3}\right)_{2}$ is 11,900 pounds $\mathrm{CaCO}_{3}$ per acre, which is only 600 pounds less than the average $\mathrm{Ca}$ added to these tanks. The suggestion from the agreement between the $\mathrm{Y}$-intercept value and the $\mathrm{Ca}$ added to the soil is that if no leaching had taken place, and no Ca had been needed to neutralize soil acidity, and no $\mathrm{Ca}$ had been removed by crops, all the $\mathrm{Ca}$ added would have precipitated as $\mathrm{CaCO}_{3}$. Thus, the formulas proposed by Eaton (1950) for estimating the $\mathrm{Na}$ hazards of waters containing $\mathrm{HCO}_{3}{ }^{-}$are appropriate if the soil is alkaline ( $\mathrm{pH}$ near 8 ), and there is no leaching or crop removal of constituents in the water. With crop removal or increased leaching the formulas overestimate the $\mathrm{Na}$ hazard. If the soil is acid the formulas do not apply until the usually alkaline $\mathrm{pH}$ values of calcareous soils are attained. 
The average $\mathrm{CaCO}_{3}$ in the soil was approximately 50 per cent of the $\mathrm{CaCO}_{3}$ equivalent of the total $\mathrm{Ca}$ added. The relationship between $\mathrm{CaCO}_{3}$ in the soil and half the $\mathrm{CaCO}_{3}$ equivalent of the $\mathrm{Ca}$ added for each of the four winter crop treatments is presented in figure 4. There was a significant correlation between the two. When all data were considered seventy-one per cent of the variations in $\mathrm{CaCO}_{3}$ in the soil was associated with variations in the measured $\mathrm{Ca}$ added. A large fraction of the unaccounted-for variation is undoubtedly a result of large differences in leaching percentage between the straw and the mustard treatments where $\mathrm{Ca}\left(\mathrm{NO}_{3}\right)_{2}$ was added. The leaching with mustard was 5.0 per cent whereas with the straw treat-

TABLE 9

CARBONATE-C CONTENT OF SOIL AND SODIUM ADSORPTION RATIO (SAR) FOR THE SATURATION EXTRACT OF FIVE DEPTHS OF SOIL FROM TANKS TREATED WITH CEREAL STRAW OR COVERCROPPED WITH MUSTARD, VETCH, AND MELILOTUS

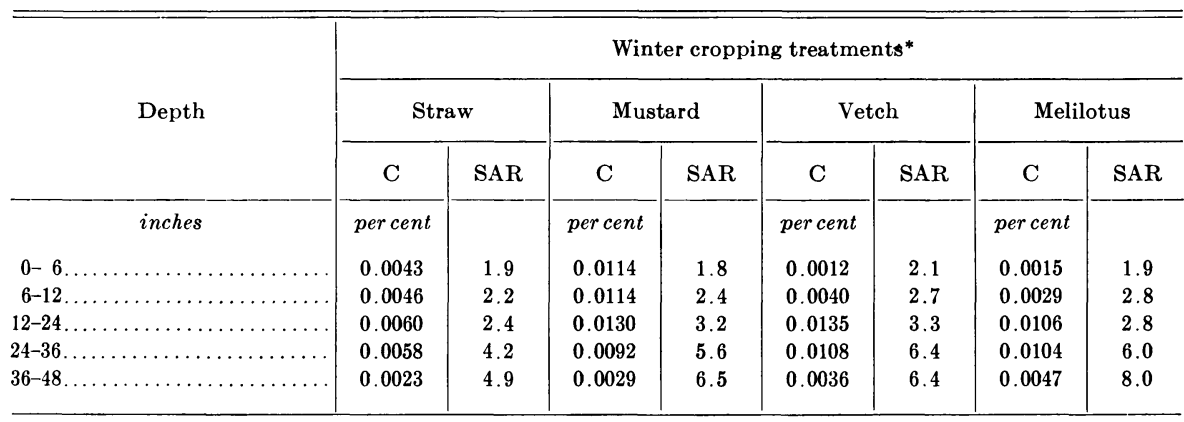

* The data for each winter cropping treatment are averages for three rates of $\mathrm{N}$ application. The $\mathrm{N}$ application increased the magnitude of the $\mathrm{CaCO}_{3}$ precipitation but had no effect on the relationships between depth and lime or depth and SAR.

ment it was 7.6 per cent. There may have also been some effect of greater $\mathrm{CO}_{2}$ production by the mustard crop than by the straw treatment.

Data for the $\mathrm{CaCO}_{3}$ equivalent of the $\mathrm{HCO}_{3}^{-}$added in the irrigation water and the $\mathrm{CaCO}_{3}$ in the soil as a per cent of the $\mathrm{HCO}_{3}^{-}$added are presented in table 8. The average precipitation of $\mathrm{HCO}_{3}{ }^{-}$was $39.9,74.0$ and 84.8 per cent, respectively, for 0,100 , and 200 pounds $\mathrm{N}$ per acre as $\mathrm{Ca}\left(\mathrm{NO}_{3}\right)_{2}$. Where $\mathrm{N}$ was added there was a greater per cent precipitation of $\mathrm{HCO}_{3}^{-}$with mustard than with the two legume crops, and this difference is not related to differences in leaching because the leaching was the same at the 100-pound $N$ rate. These data along with data of figure 4, suggest that the type of crop has an influence on $\mathrm{CaCO}_{3}$ precipitation exclusive of the effect of the crop on leaching percentage. Perhaps this difference resulted from differences in amount of Ca absorption by the crops.

The index defined by C. A. Bower (1958) was calculated for each lysimeter tank. This index is $\mathrm{pH}_{\mathrm{s}}-\mathrm{pH}_{\mathrm{c}}$ where $\mathrm{pH}_{\mathrm{s}}$ is the $\mathrm{pH}$ of the saturated soil paste and $\mathrm{pH}_{\mathrm{c}}$ is the $\mathrm{pH}$ that would be in equilibrium in $\mathrm{CaCO}_{3}$ at the $\mathrm{Ca}^{++}$ and $\mathrm{HCO}_{3}^{-}$concentrations in the irrigation water. The $\mathrm{pH}_{\mathrm{c}}$ is calculated from the following formula:

$$
\mathrm{pH}_{\mathrm{c}}=\left(\mathrm{pK}_{2}^{\prime}-\mathrm{pK}_{\mathrm{c}}{ }^{\prime}\right)+\mathrm{pCa}+\mathrm{pAlk} .
$$


Where $\mathrm{pK}_{2}{ }^{\prime}$ is the negative logarithm of the second dissociation constant of $\mathrm{H}_{2} \mathrm{CO}_{3}, \mathrm{pK}_{\mathrm{c}}{ }^{\prime}$ is the negative logarithm of the solubility product constant of $\mathrm{CaCO}_{3}$, and $\mathrm{pCa}$ and pAlk. are the negative logarithms of the $\mathrm{Ca}$ and alkalinity concentrations respectively. The alkalinity is the total alkalinity to the methyl orange end point, expressed as $\mathrm{HCO}_{3}^{-}$.

The $\mathrm{Ca}$ concentration of the irrigation water was adjusted to take into consideration the $\mathrm{Ca}$ added in straw and $\mathrm{Ca}\left(\mathrm{NO}_{3}\right)_{2}$ by dividing the total $\mathrm{Ca}$ added in the water, fertilizer, and straw, by the total volume of irrigation water applied.

The relations between per cent $\mathrm{HCO}_{3}{ }^{-}$precipitation and the modified saturation index for all cropping treatments are presented in figure 5. There

TABLE 10

EXCHANGEABLE Na PERCENTAGE AND pH FOR SOIL IN LYSIMETER TANKS COVERCROPPED TO VETCH AND TREATED WITH THREE RATES OF $\mathrm{Ca}\left(\mathrm{NO}_{3}\right)_{2}$

\begin{tabular}{|c|c|c|c|c|c|c|}
\hline \multirow{3}{*}{ Depth, inches } & \multicolumn{6}{|c|}{ Rate of $\mathrm{Ca}\left(\mathrm{NO}_{3}\right)$, lbs $\mathrm{N}$ per acre } \\
\hline & \multicolumn{2}{|c|}{0} & \multicolumn{2}{|c|}{100} & \multicolumn{2}{|c|}{200} \\
\hline & $\mathrm{pH}$ & Exch. Na & $\mathrm{pH}$ & Exch. $\mathrm{Na}$ & $\mathrm{pH}$ & Exch. Na \\
\hline $0-6 \ldots$ & 7.9 & 5.1 & 7.8 & 5.3 & 7.5 & 5.3 \\
\hline $6-12 \ldots$ & 8.0 & 4.8 & 8.0 & 4.5 & 7.8 & 4.9 \\
\hline $12-24 \ldots \ldots$ & 8.2 & 7.8 & 8.3 & 6.8 & 7.9 & 4.4 \\
\hline $24-36 \ldots$. & 8.4 & 14.9 & 8.4 & 10.5 & 8.0 & 8.5 \\
\hline $36-48 \ldots \ldots \ldots$ & 8.1 & 12.8 & 7.9 & 13.0 & 7.7 & 10.2 \\
\hline
\end{tabular}

was a significant correlation between the modified saturation index and the percentage of $\mathrm{HCO}_{3}^{-}$precipitation; there was also a difference in the crops. The combination of $\mathrm{Ca}\left(\mathrm{NO}_{3}\right)_{2}$ with mustard winter covercrop produced a greater per cent precipitation of the $\mathrm{HCO}_{3}^{-}$than the two other covercrops or the straw treatments.

Carbonate-C content and sodium adsorption ratio ( $\mathrm{SAR}$ ) of the saturation extract of soil of five depths are presented in table 9. The rate of application of $\mathrm{Ca}\left(\mathrm{NO}_{3}\right)_{2}$ (pounds $\mathrm{N}$ per acre) had no effect on relations between soil depth and lime content or SAR; thus the data were averaged for each cropping treatment.

With each treatment the maximum precipitation of lime was in soil of the 12- to 24-inch depth. In the case of the straw applications and mustard covercrop treatment, the differences in amounts of lime content of the first 2 feet of soil were not great, whereas in the legume covercrop treatments the first foot of soil contained much less lime than the second and third feet.

In all cases the greatest increase in SAR was at a depth just below that of the maximum precipitation of carbonates. Thus there is a direct causeand-effect relationship between precipitation of $\mathrm{CaCO}_{3}$ and the $\mathrm{SAR}$ of the water that moves on to the lower layers of the soil.

Both the precipitation of $\mathrm{CaCO}_{3}$ and the differential absorption by plants of $\mathrm{Ca}$ and $\mathrm{Mg}$ relative to $\mathrm{Na}$, influence the $\mathrm{SAR}$ of the water in the soil. In 


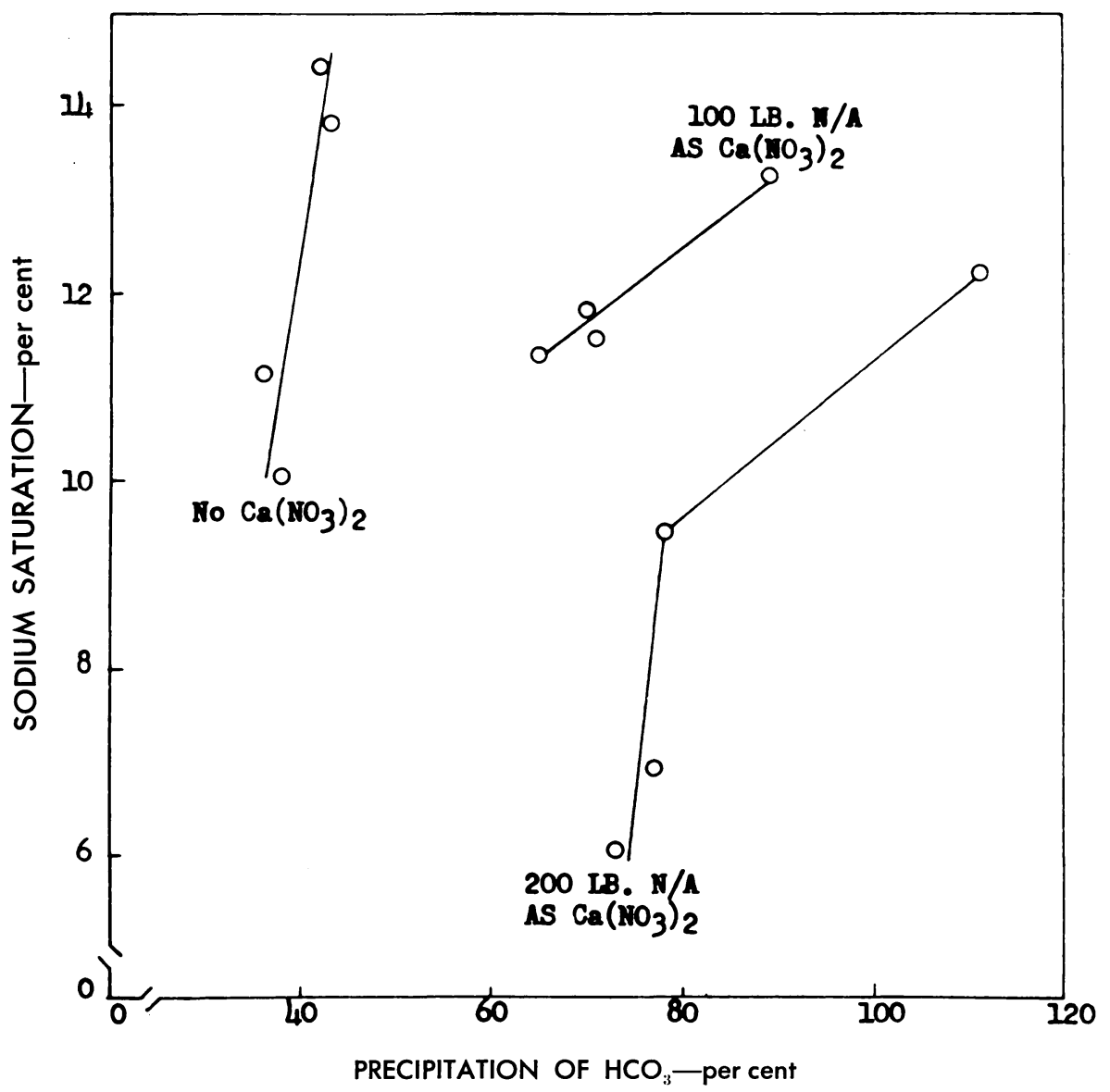

Fig. 6. Relations among Na saturation of the soil of the 24-36-inch depth, precipitation of the $\mathrm{HCO}_{3}{ }^{-}$added in the irrigation water and the annual rate of application of $\mathrm{Ca}\left(\mathrm{NO}_{3}\right)_{2}$ fertilizer.

this experiment the removal of $\mathrm{Na}$ by plants was $8.5 \%$ of that added, whereas with $\mathrm{Ca}$ and $\mathrm{Mg}$, removal by plants was 14.6 and $48 \%$, respectively. The SAR of the water was 1.16 ; thus all saturation extracts showed a higher SAR than the water.

Data for $\mathrm{pH}$ and per cent exchangeable $\mathrm{Na}$ for soils winter-covercropped to vetch at three rates of $\mathrm{N}$ are presented in table 10. The data for the third foot of soil at the $\mathrm{O}$ rate of $\mathrm{N}$ show that the soil at this depth was approaching alkali or sodic characteristics. The $\mathrm{Ca}\left(\mathrm{NO}_{3}\right)_{2}$ applications had a soil amendment effect in reducing both the $\mathrm{pH}$ and the per cent exchangeable $\mathrm{Na}$ at the lower depths.

The relations among $\mathrm{Na}$ saturation of the 24- to 36-inch depth of soil, precipitation of the $\mathrm{HCO}_{3}{ }^{-}$added in the irrigation water, and the rate of application of $\mathrm{N}$ as $\mathrm{Ca}\left(\mathrm{NO}_{3}\right)_{2}$ are presented in figure 6 . These data provide 
additional evidence that the precipitation of $\mathrm{CaCO}_{3}$ increased the sodium saturation and also that the $\mathrm{Ca}\left(\mathrm{NO}_{3}\right)_{2}$ served as a soil amendment in reducing sodium saturation. Within each rate of application of $\mathrm{Ca}\left(\mathrm{NO}_{3}\right)_{2}$ the $\mathrm{Na}$ saturation increased with increase in $\mathrm{CaCO}_{3}$ precipitation. The overall effect, however, of the $\mathrm{Ca}\left(\mathrm{NO}_{3}\right)_{2}$ was to reduce $\mathrm{Na}$ saturation.

Salts in Drainage Water. Data for the amounts of soluble constituents of the drainage water for the 1951-52 season are presented in table 11. This leaching followed a period of 7 years in which there was no drainage water and thus represents the maximum salt content of the drainage water in the experiment. The solution was mainly a mixture of sulfate salts with about

Table 11

ANALYSIS OF DRAINAGE WATER FOR 1951-52 SEASON

\begin{tabular}{|c|c|c|c|c|c|c|c|c|c|c|}
\hline \multirow{2}{*}{$\begin{array}{c}\text { Tank number } \\
\text { and } \\
\text { treatment }\end{array}$} & \multirow{2}{*}{ Acre-inches } & \multirow{2}{*}{$\mathrm{pH}$} & \multicolumn{8}{|c|}{ Composition of drainage (me/liter) } \\
\hline & & & $\mathrm{Ca}$ & $\mathrm{Mg}$ & $\mathrm{Na}$ & $\mathrm{K}$ & $\begin{array}{c}\mathrm{CO}_{3} \\
\mathrm{HCO}_{3}\end{array}$ & $\mathrm{Cl}$ & $\mathrm{SO}_{4}$ & $\mathrm{NO}_{3}$ \\
\hline \multirow[t]{3}{*}{ 1. Straw........ } & 1st. & 7.0 & 24.8 & 13.7 & 18.3 & 0.2 & 1.0 & 4.3 & 50.8 & 1.0 \\
\hline & $2 \mathrm{~d}$. & 7.1 & 20.6 & 10.7 & 15.8 & 0.2 & 1.8 & 3.7 & 42.2 & 1.4 \\
\hline & $3 \mathrm{~d}$. & 7.6 & 13.4 & 7.1 & 11.5 & 0.1 & 1.8 & 4.3 & 26.1 & 2.2 \\
\hline 2. Vetch. & 1 st $2 / 3$. & 8.1 & 20.0 & 9.3 & 25.9 & 0.4 & 3.2 & 5.8 & 40.3 & 9.9 \\
\hline \multirow[t]{3}{*}{ 3. Melilotus..... } & 1st... & 7.3 & 23.4 & 13.1 & 30.8 & 0.4 & 4.9 & 5.0 & 56.7 & 2.7 \\
\hline & $2 \mathrm{~d} \ldots .$. & 8.2 & 19.1 & 8.8 & 27.2 & 0.3 & 5.3 & 4.0 & 46.2 & 2.6 \\
\hline & $3 \mathrm{~d} . . .$. & 8.4 & 14.3 & 6.5 & 22.6 & 0.2 & 7.5 & 2.9 & 34.1 & 1.9 \\
\hline \multirow[t]{6}{*}{ 4. Mustard...... } & 1st.. & 7.7 & 22.9 & 10.7 & 18.7 & 0.2 & 4.5 & 4.6 & 44.1 & 0.1 \\
\hline & $2 \mathrm{~d} \ldots \ldots \ldots \ldots$ & 7.6 & 19.7 & 9.1 & 16.8 & 0.2 & 5.0 & 4.7 & 36.6 & 0.1 \\
\hline & $3 \mathrm{~d} \ldots \ldots \ldots \ldots$ & 8.2 & 14.7 & 6.5 & 15.4 & 0.1 & 5.3 & 4.4 & 26.9 & 0.2 \\
\hline & 4 th $\ldots \ldots \ldots$ & 8.2 & 12.5 & 5.8 & 13.7 & 0.1 & 5.9 & 4.0 & 21.9 & $<0.0$ \\
\hline & 5 th...... & 8.1 & 11.1 & 5.3 & 13.3 & 0.1 & 7.4 & 3.8 & 19.6 & 0.1 \\
\hline & 6 th........... & 8.4 & 8.0 & 4.1 & 10.6 & 0.1 & 8.0 & 2.8 & 14.0 & 0.1 \\
\hline
\end{tabular}

equal amounts of $\mathrm{Na}$ and $\mathrm{Ca}$. The $\mathrm{Cl}$ content was low because the crops removed 81 per cent of that added, and the $\mathrm{HCO}_{3}{ }^{-}$was low because of precipitation as $\mathrm{CaCO}_{3}$. Relative to the composition of the irrigation water the $\mathrm{Na}$ and $\mathrm{SO}_{4}$ ions showed the greatest concentration effect.

Exchangeable Cations in the Soil. The soil as it was put into the tanks had a uniform depth distribution of exchangeable cations. Thus any differences found at the end of the experiment are a result of changes that have resulted from crops, irrigation water, and fertilizer.

The depth distribution of the eation-exchange capacity changed only slightly. The C.E.C. of the surface six inches was 7.1 compared to a value of about 6.2 in the lower depths. This difference is probably a result of some accumulation of organic matter in the surface and loss of organic matter at the lower depths.

The average depth distribution of exchangeable $\mathrm{K}$ was $4.6,3.0,2.3,2.2$ and 2.1 per cent saturation for soil of the $0-6,6-12,12-24,24-36$ and 36-48inch depths respectively. For the most part, distribution is probably a result of the deposition of $K$ on the surface soil by growth of the winter crops. The only treatment that included additions of $\mathrm{K}$ to the soil was application 
SATURATION-per cent

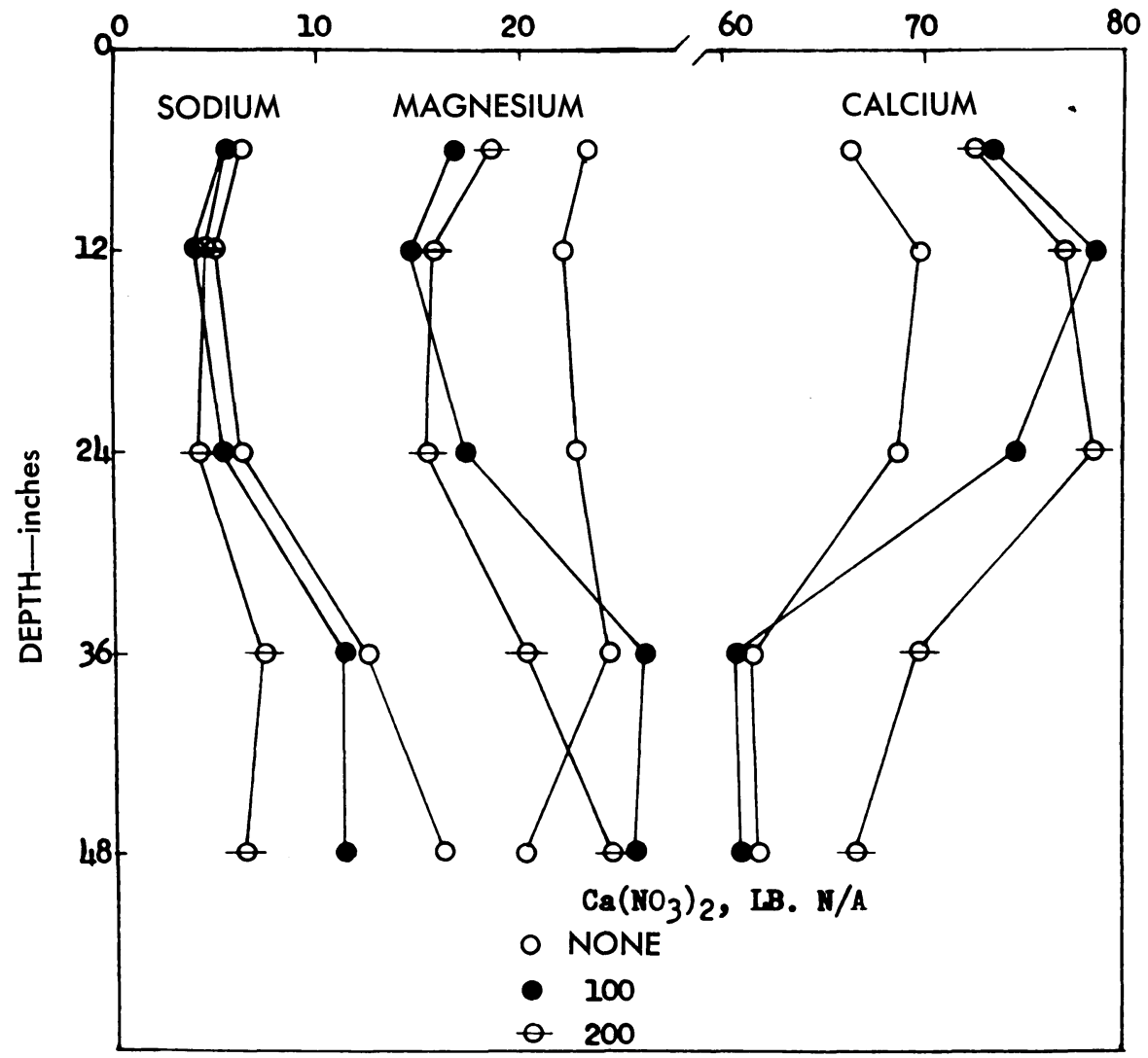

Fig. 7. Relations among saturation of soil with $\mathrm{Ca}, \mathrm{Mg}$, and $\mathrm{Na}$ depth of soil and rate of application of $\mathrm{Ca}\left(\mathrm{NO}_{3}\right)_{2}$ fertilizer.

of cereal straw. However, the distribution of exchangeable $\mathrm{K}$ was qualitatively the same in all tanks, although the highest $\mathrm{K}$ saturation in the surface six inches of soil was in tanks that received cereal straw.

The relations among saturation of the soil with $\mathrm{Ca}, \mathrm{Mg}$ and $\mathrm{Na}$, depth of soil and rate of application of $\mathrm{Ca}\left(\mathrm{NO}_{3}\right)_{2}$ are presented in figure 7. The increased Ca saturation of the surface 0 to 24-inch depth of soil that resulted from the application of $\mathrm{Ca}\left(\mathrm{NO}_{3}\right)_{2}$ was mainly balanced by a decrease in $\mathrm{Mg}$ saturation. In the soil at the lower depths the $\mathrm{Mg}$ saturation at the intermediate $\mathrm{Ca}\left(\mathrm{NO}_{3}\right)_{2}$ level increased with a corresponding decrease in $\mathrm{Na}$ saturation and, at the highest rate of $\mathrm{Ca}\left(\mathrm{NO}_{3}\right)_{2}, \mathrm{Ca}$ increased with a decrease in both $\mathrm{Mg}$ and $\mathrm{Na}$.

Under the conditions of the experiment the Ca added in water and in fertilizer was sufficient to prevent Na accumulation in the 0 to 24-inch depth of soil and also sufficient to replace $\mathrm{Mg}$. The replaced $\mathrm{Mg}$ moved down and partially prevented $\mathrm{Na}$ accumulation in the lower depths. The data suggest 


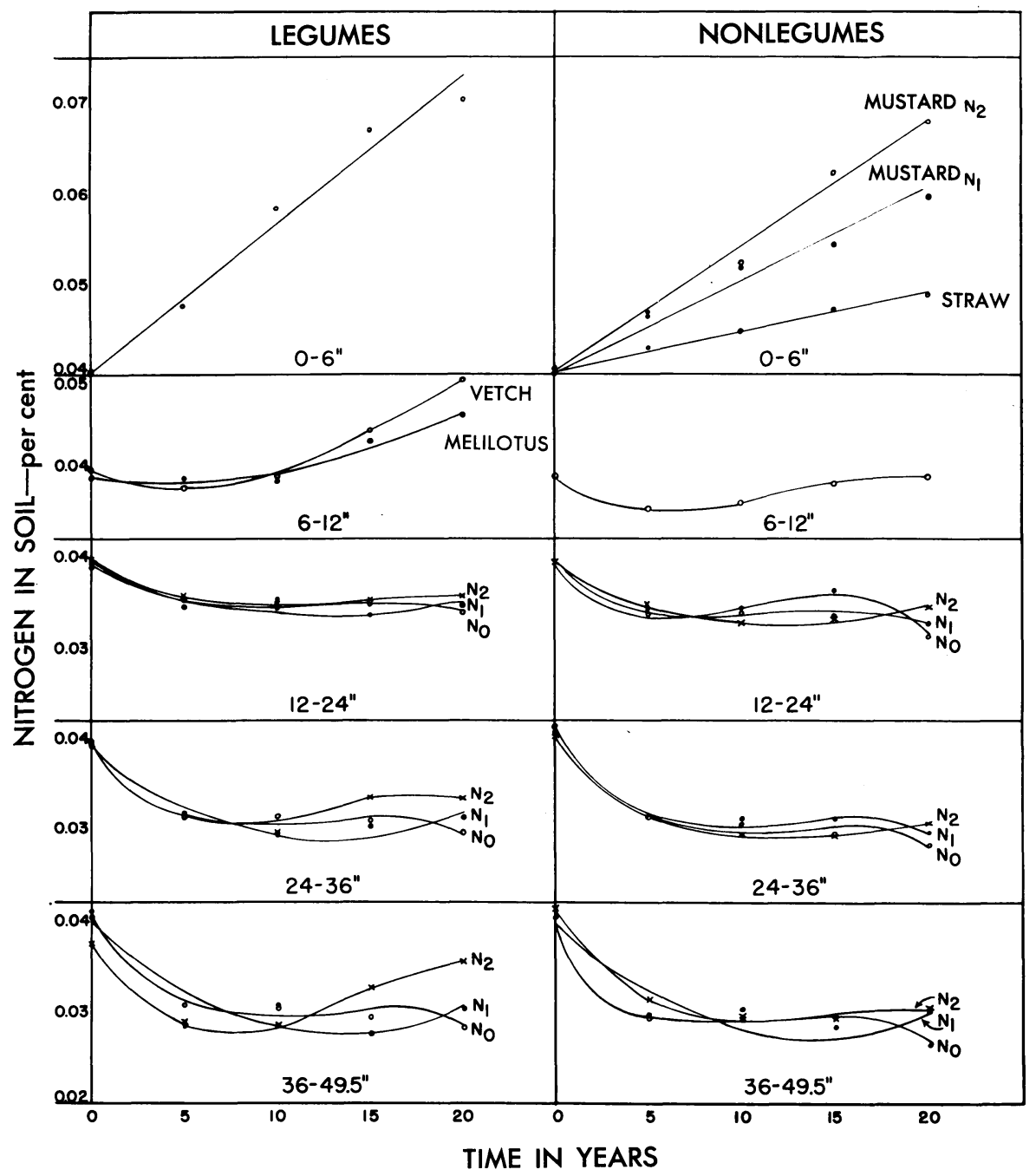

Fig. 8. Relationships between total $\mathrm{N}$ in soil at five depths and time for legumes, nonlegumes and three rates of $\mathrm{N}$ application.

that a slightly higher leaching percentage would have prevented $\mathrm{Na}$ accumulation in the lower depths but would have also greatly increased the Mg loss.

Total Nitrogen and Organic Carbon in the Soil. The relations between total $\mathrm{N}$ in the soil, depth of soil and time in years beginning with treatments in 1933 are presented in figure 8. The first seven years of fallow made little or no difference in the total $\mathrm{N}$ in the soil. Any nitrate produced must have stayed where it was produced because the depth distribution of total $\mathrm{N}$ did not change during the fallow period. To produce the curves shown in figure 


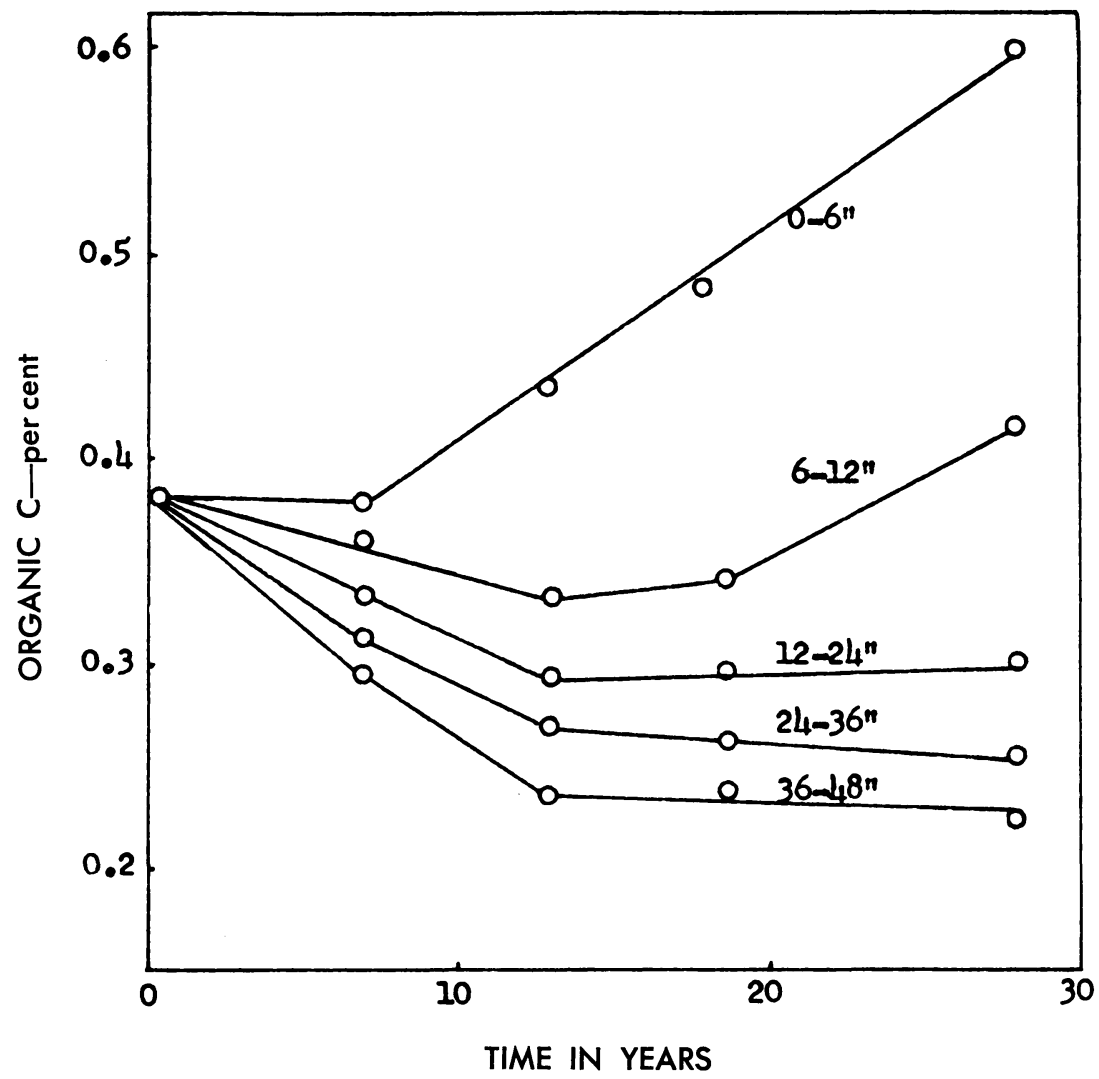

Fig. 9. Relation between organic $\mathrm{C}$ in the soil and time beginning when the soil was placed in the lysimeters. The treatment for the tank from which these data were obtained was growth of vetch with no $\mathrm{N}$ application.

8 the data were combined until statistically significant differences in regression coefficients were found, and these regression equations were plotted in the figure along with the data. Thus all differences shown in the figure are statistically significant.

The legumes and mustard with added $\mathrm{N}$ increased the total $\mathrm{N}$ in the surface six inches of soil. In all cases there was a decrease and then an increase in the 6 - to 12-inch depth of soil. In the depths below 12 inches there was a decrease with time with an indicated equilibrium attained after 10 years of treatment or 17 years of total time the soil was in the tanks. Small variations in total $\mathrm{N}$ in the lower depths during the last 10 years were associated with variations in $\mathrm{NO}_{3}-\mathrm{N}$ accumulation from $\mathrm{Ca}\left(\mathrm{NO}_{3}\right)_{2}$ applications.

The relation between organic $\mathrm{C}$ in the soil and time beginning when the soil was placed in the tanks is presented in figure 9 . The data in figure 9 are for soil treated with vetch winter crop with no $\mathrm{N}$ applied. All other tanks were similar, except for very small differences in the amount of 
organic $\mathrm{C}$ in the soil below 6 inches and some differences in organic $\mathrm{C}$ in the 0 - to 6 -inch depth.

During the first seven vears the soil was fallowed with no vegetation allowed to grow. Thus the decrease in organic $\mathrm{C}$ during these years is entirely a result of differences in rate of oxidation of organic matter and in no way is related to differences between production and destruction. The most logical explanation for the fact that organic $C$ disappeared faster in the lower horizons is as follows: During the rainy reason, when moisture was adequate for mineralization of organic matter, the soil was too cool ; when soil became sufficiently warm the rainy season was completed, surface soil was dry, and the moisture increased with increase in depth so that the rate of decomposition of organic matter increased with increase in depth. When cropping started production minus decomposition was greatest in the surface layer and decreased with increase in depth so that the trends started in the first 7 years with a fallow system were continued under the cropping system. The attainment of equilibrium at the lower depths and reversal of the downward trend in the 6 - to 12-inch depth coincided with the change of the summer crop from barley to Sudangrass. The depth distribution of organic $\mathrm{C}$ in the soil at the end of the experiment was nearly the same as the distribution of organic $\mathrm{C}$ in the agricultural soils in the area where the experiment was conducted.

\section{SUMMARY}

The data from a 20-year lysimeter investigation with an irrigated soil have been presented and discussed. The following paragraphs summarize the results.

Yields of Crops. Applications of $\mathrm{N}$ to winter annual legumes produced small but consistent increases in yields. There were large increases in yields of winter-grown mustard as a result of $\mathrm{N}$ applications. The summer crop, which was barley for the first 6 years and the Sudangrass the rest of the time, gave no increased yield from $\mathrm{N}$ where a winter legume was grown and turned under and relatively small increases where mustard was grown as a winter crop or where straw was added in the winter.

The growth of vetch and melilotus winter legumes were as effective as mustard as a winter crop plus 135 pounds $\mathrm{N}$ per acre in supplying the summer crop with $\mathrm{N}$.

Nitrogen. Nitrogen fixation by the winter legumes was 131,106 , and 77 pounds per acre per year for vetch treated with 0,100 and 200 pounds $\mathrm{N}$ per acre per year respectively. Comparable data for melilotus were 124, 82 and 67 pounds $\mathrm{N}$ per acre per year respectively. There were no significant gains or losses of $\mathrm{N}$ in the tanks treated with straw or the growth of mustard in combination with $\mathrm{N}$ applications.

Phosphorus. The average depletion of $\mathrm{P}$ from the soil was 15.9 pounds $\mathrm{P}$ per acre per year.

Potassium. The average depletion of $\mathrm{K}$ was 181 pounds $\mathrm{K}$ per acre per year.

Magnesium. There was a small average loss of $\mathrm{Mg}$ from the soil. However within each winter crop or crop residue treatment there was a decrease in 
$\mathrm{Mg}$ accumulation or an increase in $\mathrm{Mg}$ loss with increase in the rate of application of $\mathrm{N}$ as $\mathrm{Ca}\left(\mathrm{NO}_{3}\right)_{2}$.

Sodium. The average $\mathrm{Na}$ accumulation was 116 pounds per acre per year, which was 69 per cent of the $\mathrm{Na}$ added.

Chloride. The average accumulation of $\mathrm{Cl}$ was 3 pounds per acre per year or about 2 per cent of that added. About 81 per cent of the added Cl was removed by the summer crop and about 17 per cent was removed by leaching.

Sulfur. The average $\mathrm{S}$ accumulation was 16.8 pounds per acre per year which was 48 per cent of that added.

Calcium. The average $\mathrm{Ca}$ accumulation was 62 per cent of that added. Eighty-six per cent of the $\mathrm{Ca}$ accumulated was precipitated as $\mathrm{CaCO}_{3}$ in the soil and 14 per cent was used in neutralizing soil acidity. The $\mathrm{CaCO}_{3}$ precipitated in the soil was significantly related to leaching percentage, type of crop and to total $\mathrm{Ca}$ added. The $\mathrm{Ca}$ added as $\mathrm{Ca}\left(\mathrm{NO}_{3}\right)_{2}$ had a soil amendment effect in reducing the exchangeable Na.

Drainage Water. Because of crop removal of $\mathrm{Cl}$ and precipitation of $\mathrm{HCO}_{3}{ }^{-}$ as $\mathrm{CaCO}_{3}$ the drainage water in the 1951-52 season was mainly a solution of $\mathrm{SO}_{4}$ salts. Sodium and $\mathrm{SO}_{4}$ showed the greatest concentration relative to the composition of the irrigation water.

Exchangeable Cations in the Soil. The exchangeable K decreased with increase in depth. $\Lambda$ pplications of $\mathrm{Ca}$ as $\mathrm{Ca}\left(\mathrm{NO}_{3}\right)_{2}$ displaced $\mathrm{Mg}$ from the surface layers (0- to 24-inches) and prevented accumulation of $\mathrm{Na}$ in the soil of the same depth. Exchangeable $\mathrm{Na}$ accumulated in the 24- to 48-inch depth and where $\mathrm{Ca}\left(\mathrm{NO}_{3}\right)_{2}$ was added exchangeable $\mathrm{Mg}$ accumulated in the same depths.

Total Nitrogen and Organic Carbon. Losses of $\mathrm{N}$ and organic $\mathrm{C}$ were greatest at the lowest depths. The surface soil increased in both $\mathrm{N}$ and organic $\mathrm{C}$ during the 20 years of cropping but there were no changes during the 7 years of fallow that preceded the cropping period. However, during the fallow period the lower depths lost organic C.

\section{LITERATURE CITED}

Allison, F. E.

1955. The enigma of the soil nitrogen balance sheets. Adv. in Agron. $7: 213-250$.

Bower, C. A.

1958. Prediction of the effects of irrigation waters on soils. Proc. UNESCO Arid Zone Symposium. Tehran, Iran.

BrondBent, F. E., and H. D. Chapman

1950. A lysimeter investigation of gains, losses, and balance of salts and plant nutrients in an irrigated soil. Soil Sci. Soc. Amer. Proc. (1949) 14: 261-269.

Chapman, H. D., G. F. Liebig, and D. D. RaYNer

1949. A lysimeter investigation of nitrogen gains and losses under various systems of covercropping and fertilization, and a discussion of error sources. Hilgardia 19: $57-128$.

EAToN, F. M.

1950. Significance of carbonates in irrigation waters. Soil Sci. 69: 123-133.

Pratt, P. F., and R. B. Harding

1957. Decreases in exchangeable magnesium in an irrigated soil during 28 years of differential fertilization. Agron. Jour. 49: 419-421. 

The journal Hilgardia is published at irregular intervals, in volumes of about 600 pages. The number of issues per volume varies.

Subscriptions are not sold. The periodical is sent as published only to libraries, or to institutions in foreign countries having publications to offer in exchange.

You may obtain a single copy of any issue free, as long as the supply lasts; please request by volume and issue number from:

\section{Agricultural Publications \\ 207 University Hall \\ 2200 University Avenue \\ Berkeley 4, California}

The limit to nonresidents of California is 10 separate issues on a single order. A list of the issues still available will be sent on request. 
